\title{
Timing, drivers and impacts of the historic Masiere di Vedana rock avalanche (Belluno Dolomites, NE Italy)
}

\author{
Sandro Rossato ${ }^{1}$, Susan Ivy-Ochs ${ }^{2}$, Silvana Martin ${ }^{1}$, Alfio Viganò ${ }^{3}$, Christof Vockenhuber ${ }^{2}$, Manuel Rigo ${ }^{1}$, \\ Giovanni Monegato ${ }^{4}$, Marco De Zorzi ${ }^{2}$, Nicola Surian ${ }^{1}$, Paolo Campedel ${ }^{3}$, and Paolo Mozzi ${ }^{1}$ \\ ${ }^{1}$ Department of Geosciences, University of Padua, Via Gradenigo, 6, 35131 Padua, Italy \\ ${ }^{2}$ Laboratory of Ion Beam Physics, Otto-Stern-Weg 5, ETH-Honggerberg, 8093 Zurich, Switzerland \\ ${ }^{3}$ Servizio Geologico, Provincia autonoma di Trento, Via Zambra 42, 38122 Trento, Italy \\ ${ }^{4}$ National Research Council, Institute of Geosciences and Earth Resources, Padua, Italy
}

Correspondence: Sandro Rossato (sandro.rossato@unipd.it)

Received: 13 December 2019 - Discussion started: 14 February 2020

Revised: 18 May 2020 - Accepted: 29 June 2020 - Published: 12 August 2020

\begin{abstract}
The "Masiere di Vedana" rock avalanche, located in the Belluno Dolomites (NE Italy) at the foot of Mt. Peron, is reinterpreted as historic on the base of archeological information and cosmogenic ${ }^{36} \mathrm{Cl}$ exposure dates. The deposit is $9 \mathrm{~km}^{2}$ wide, has a volume of $\sim 170 \mathrm{Mm}^{3}$ corresponding to a pre-detachment rock mass of $\sim 130 \mathrm{Mm}^{3}$, and has a maximum runout distance of $6 \mathrm{~km}$ and an $H / L$ ratio of $\sim 0.2$. Differential velocities of the rock avalanche moving radially over different topography and path material lead to the formation of specific landforms (tomas and compressional ridges). In the Mt. Peron crown the bedding is subvertical and includes carbonate lithologies from Lower Jurassic (Calcari Grigi Group) to Cretaceous (Maiolica) in age. The stratigraphic sequence is preserved in the deposit with the formations represented in the boulders becoming younger with distance from the source area. In the release area the bedding, the SSE-verging frontal thrust planes, the NW-verging backthrust planes, the NW-SE fracture planes, and the N$S$ Jurassic fault planes controlled the failure and enhanced the rock mass fragmentation. The present Mt. Peron crown still shows hundreds-of-metres-high rock prisms bounded by backwall trenches. Cosmogenic ${ }^{36} \mathrm{Cl}$ exposure ages, mean $1.90 \pm 0.45 \mathrm{ka}$, indicate failure occurred between $340 \mathrm{BCE}$ and $560 \mathrm{CE}$. Although abundant Roman remains were found in sites surrounding the rock avalanche deposit, none were found within the deposit, and this is consistent with a late Roman or early Middle Ages failure. Seismic and climatic conditions as landslide predisposing factors are discussed. Over the last few hundred years, earthquakes up to $M_{\mathrm{w}}=6.3$, in-
\end{abstract}

cluding that at $365 \mathrm{CE}$, have affected the Belluno area. Early in the first millennium, periods of climate worsening with increasing rainfall occurred in the NE Alps. The combination of climate and earthquakes induced progressive long-term damage to the rock until a critical threshold was reached and the Masiere di Vedana rock avalanche occurred.

\section{Introduction}

Landslides have an enormous impact on landscapes and can be a serious threat to human lives and buildings. Assessment of the potential for future events is distinctly dependent on knowledge of the conditions under which past failures occurred in the immediate vicinity (Samia et al., 2017). This entails detailed analysis and interpretation of driving factors as well as possible triggers of past events (Eisbacher and Clague, 1984; Nicoletti and Sorriso-Valvo, 1991; Hungr, 2006; Strom, 2006; Hermanns and Longva, 2012). Bedrock bedding, faults, fractures and other discontinuities predispose a rock mass to fail (Stead and Wolter, 2015). Damage accumulation in rock (fatigue) contributes to the location of failure (Friedmann et al., 2003; Brideau et al., 2009; Parker et al., 2013; Stead and Eberhardt, 2013; Preisig et al., 2015), while seismic shakings (Keefer, 1993; Friedmann et al., 2003; Dunning et al., 2007; Cui et al., 2011; Stead and Eberhardt, 2013) and periods of extreme rainfall (Guzzetti et al., 2008; Tsai and Wang, 2011; Loew et al., 2017; Preisig et al., 2015) can trigger landslides. 


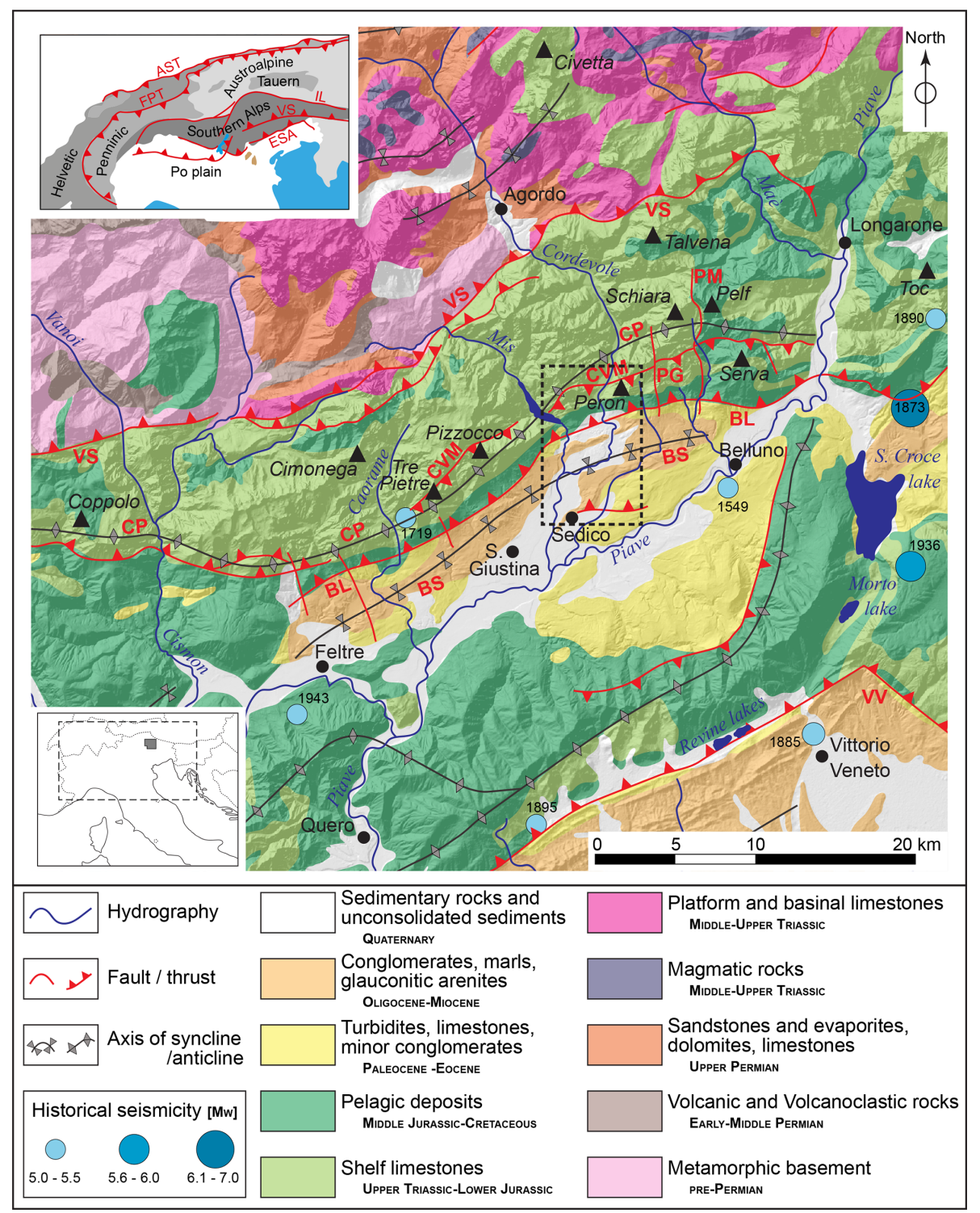

Figure 1. Simplified regional geological map (black dashed-line box indicates location of Fig. 3). The map is based on Bosellini et al. (1981), Masetti and Bianchin (1987), Bigi et al. (1990), and Costa et al. (1996). Epicentres of earthquakes from the last 2 millennia are shown with colour coding and year of occurrence (source: Parametric Catalogue of Italian Earthquakes, 2015 version Rovida et al., 2016). The base map is the SRTM-derived digital elevation model (30 m cells) (source: http://viewfinderpanoramas.org/, last access: 17 October 2019). The structural setting is shown in the upper left inset (based on Doglioni, 1990). AST: Alpine Sole thrust; BL: Belluno thrust; BS: Belluno syncline; CP: Coppolo-Pelf anticline; CVM: Val Carpenada-Val di Vido-Val Madonuta thrust; ESA: eastern Southern Alps thrust system; FPT: frontal Penninic thrust; IL: Insubric line; PG: Pala Alta-Gresal; PM: Pala Bassa-Val Medone; VS: Valsugana thrust; VV: Vittorio Veneto thrust.

From this perspective, the Italian landslide inventory project (IFFI; Trigila et al., 2007; http: //www.progettoiffi.isprambiente.it/lcartografia-on-line/, last access: 11 May 2020) is the ideal starting point for hazard maps. These are tools for landscape management and civil protection plans. They thus require continuous updating and accurate input data. In the study area (Fig. 1), the southern side of Mt. Peron (Belluno Dolomites, NE Italy) is classified in the most recent landslide hazard map (http://www.geoviewer.isprambiente.it, last access: 11 May 2020) as an "attention area" (i.e. a failure is possible, but an evaluation is needed). In 2011 a rockfall (volume $\sim 1000 \mathrm{~m}^{3}$, blocks up to $2.5 \mathrm{~m}^{3}$ ) detached from the upper part of Mt. Peron, which led the Municipality of Peron to commission the evaluation of the hazard along its southern cliff (Di Giusto, 2012). Numerous partially detached rock prisms were recognised, up to $18000 \mathrm{~m}^{3}$ and with trenches 
up to $50 \mathrm{~cm}$ wide. According to Di Giusto (2012), nine out of 16 pillars are at risk for failure in the case of an earthquake.

The IFFI catalogue, the landslide hazard map and the evaluation by Di Giusto focused on the Mt. Peron southern wall and the scree slope, neglecting the well-known deposit of Masiere di Vedana that lies on the southern plain (Abele, 1974; Eisbacher and Clague, 1984; Pellegrini et al., 2006). This is also known as "Rovine di Vedana" (Mazzuoli, 1875; Squinabol, 1902; Montandon, 1933) or "Marocche di Vedana" (Dal Piaz, 1912; Venzo, 1939). The deposit covers an area of $8-9 \mathrm{~km}^{2}$, has a maximum thickness of $40 \mathrm{~m}$ and has an estimated volume of 100-120 $\mathrm{Mm}^{3}$ (Abele, 1974; Genevois et al., 2006; Pellegrini et al., 2006). The Masiere di Vedana is one of the largest catastrophic events in the Alps (Heim, 1932; Abele, 1974; Eisbacher and Clague, 1984), comparable with large events in the Himalayas (e.g. Hewitt, 2006; Hewitt et al., 2008; Mitchell et al., 2007), Rocky Mountains (e.g. Blais-Stevens et al., 2011; Charrière et al., 2016) and Andes (e.g. Hermanns et al., 2004; Welkner et al., 2010).

As there is no consensus on the age and dynamics of the Masiere di Vedana, a re-evaluation is needed in light of hazard assessment. The Masiere di Vedana deposit was interpreted as a glacial deposit (Hoernes, 1892), a landslide transported by a glacier during the late glacial (Mazzuoli, 1875; Squinabol, 1902; Dal Piaz, 1912; Venzo, 1939) and as the result of a catastrophic flood due to collapse of a natural dam (Taramelli, 1883). Some other authors proposed as origin for the deposit (1) the combined effect of a landslide over a glacier, followed by a second landslide that evolved into a rock avalanche (Pellegrini, 2000; Pellegrini et al., 2006), and (2) a small rockslide followed by a larger rock avalanche (Genevois et al., 2006). The age attribution for the deposit ranges from the late glacial (Pellegrini et al., 2006) to historical times (Piloni, 1607; Miari, 1830).

Amongst all types of landslides, rock avalanches are particularly relevant, being both difficult to predict (Hungr, 2006) and representative of a very high risk for the population living in mountain areas (Guzzetti, 2000; Hungr, 2004; Geertsema et al., 2006; Evans et al., 2007; Sosio et al., 2008; Cui et al., 2011; Hermanns and Longva, 2012; Mitchell et al., 2020). The moving masses are composed of dry debris, which in subaerial settings ranges from about 0.5 to more than $10000 \mathrm{Mm}^{3}$ (Crosta et al., 2007). The initial phase, rockfall or rockslide, evolves into a flow-like movement of crumbling rock debris, sized from clay/silt up to decametric boulders, which can travel for several kilometres, even uphill, and overcome obstacles up to some hundreds of metres high (e.g. Hungr et al., 2001; Mangeney et al., 2010; Bowman et al., 2012). Rock avalanche deposits are characterised by inverse grading of the sediment, with large blocks dominating the carapace, the inclusion of path material and, in some cases, preservation of the stratigraphic sequence (Hewitt, 2002; Strom, 2006).
The aim of this study is to provide dating and to evaluate driving factors, potential triggers, and process dynamics of the Masiere di Vedana rock avalanche, in light of a better assessment of the hazard, potential extent and runout in similar settings.

\section{Geological setting}

The Masiere di Vedana lies at the mouth of the Cordevole Valley in a broad plain at the confluence of the Cordevole and Piave rivers (Fig. 1). Mt. Peron (1486 m a.s.1.) is the southwestern peak of the Schiara Group (highest peak: Mt. Schiara: $2565 \mathrm{~m}$ a.s.1.). Mt. Peron is composed, from the west to the east, by the Calcari Grigi Group (LowerMiddle Jurassic), Vajont Limestone (Middle Jurassic), Fonzaso Formation, and Rosso Ammonitico (Upper Jurassic) and Maiolica (Cretaceous) limestones. Their distinctive characteristics, useful for tracking the source of the Masiere di Vedana deposit, are thick-bedded, fossiliferous blue-grey limestones (Calcari Grigi Group); and thick-bedded, locally oolitic limestones and calcarenites (Vajont Limestone); thick-bedded siliceous limestones with clay interbeds (Fonzaso Fm.); pink to red nodular limestones rich in ammonites (Rosso Ammonitico); thick-bedded, white limestones with chert nodules (usually grey to black) containing nannofossils, calpionellids and radiolaria (Maiolica). Scaglia Rossa and the Cenozoic formations (Belluno flysch, Belluno glauconitic sandstone, Bastia siltstone, Libano sandstone and Bolago marl) crop out at the base of the Piz Vedana (Fig. 3), form the Castel Cuch ridge and underlie the fluvial plain between the Mis and Cordevole rivers. Outcrops of cemented Pleistocene fluvial gravels ("Roe" or "Sass Muss conglomerate"; Costa et al., 1996) are located just to the west of the present course of the Cordevole River (near the town of Vignole in Fig. 3).

The investigated area is bounded by Alpine tectonic lineaments (Fig. 1): the Valsugana thrust fault to the north, and the S-verging Alpine folds and thrusts to the south (Doglioni, 1990). Mt. Peron belongs to the hanging wall of the WSWENE-oriented Belluno thrust, one of the main tectonic lineaments of the eastern Southern Alps (Doglioni, 1990; Galadini et al., 2005), which crops out at the northern limb of the Belluno syncline. The sedimentary strata of the forelimb are sub-vertical to slightly overturned (Doglioni, 1990; Costa et al., 1996), and they converge into the Belluno thrust. The Val Carpenada - Val di Vido - Val Madonuta thrust is the backthrust of the Belluno thrust (Costa et al., 1996). To the east, reactivated Jurassic faults (Masetti and Bianchin, 1987) displaced the Val Carpenada - Val di Vido - Val Madonuta thrust (Fig. 1) and induced a wealth of fractures in the Mt. Peron rock wall (Fig. 2). The Mt. Peron is at the nucleus of an ENE-WSW-oriented anticline with a very steep forelimb, followed southwards by the Belluno syncline (Fig. 2a) that hosts Cenozoic sedimentary units (Costa et al., 1996). 


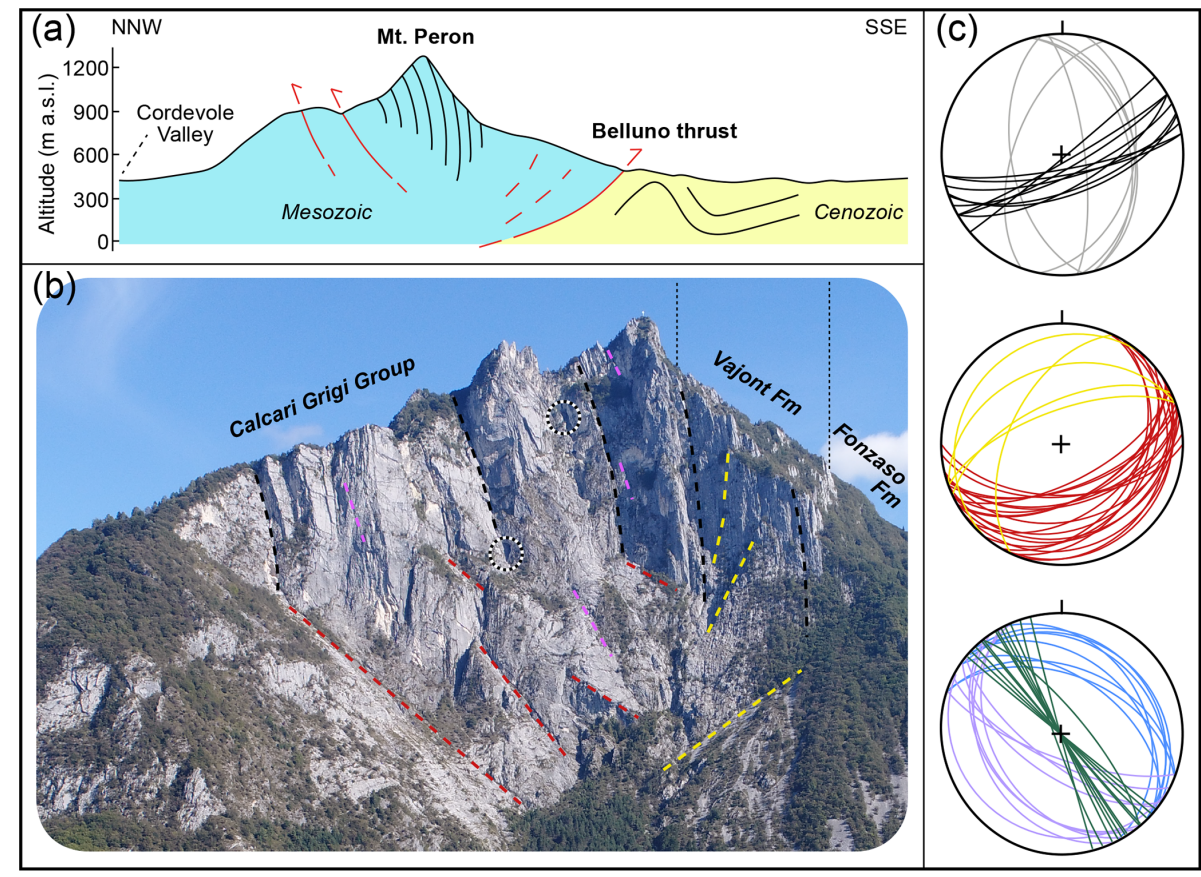

Figure 2. Structural scheme of the Mt. Peron release scarp. (a) Schematic geological cross section. (b) Photograph with major structural elements and larger karst caves (black-and-white circles) highlighted. (c) Lower-hemisphere stereographic projection of principal structural elements. Colours in (b) and (c) correspond to the following: bedding (black), N-S reactivated Jurassic fault-related planes (grey), basal trenches and other high-angle fractures connected to the Belluno thrust (yellow) and backthrust (red), fractures related to the NNW-SSE fault system (light blue), their conjugates (pink), and high-angle fractures with the same orientation (green).

\section{Methods}

\subsection{Field survey, structural analysis and remote sensing}

Detailed geomorphological maps (Caneve, 1985; De Zorzi, 2013), aerial and satellite images (Google Earth and Bing databases), and DTM analysis (cell size: $5 \mathrm{~m}$, vertical accuracy: $30 \mathrm{~cm}$; http://idt.regione.veneto.it/app/metacatalog/, last access: 17 October 2019) were used to obtain topographic profiles and to estimate the area of the Masiere di Vedana deposit. The areal distribution of lithologies in the deposit was gauged by observation of boulders in the field and verified by thin-section analysis (Sect. S1 in the Supplement). Six boreholes, up to $3 \mathrm{~m}$ deep, were taken in the finegrained sediments of the Torbe area (Fig. S2a) with a hand auger (Edelman combination type, Ejikelkamp ${ }^{\mathrm{TM}}$ ), which allows the extraction of $10 \mathrm{~cm}$ wide cylindrical cores. Orientations of bedrock discontinuities, such as bedding, foliation, joints, fractures and faults, were measured in the southern wall of Mt. Peron.

\subsection{Cosmogenic ${ }^{36} \mathrm{Cl}$ exposure dating}

Twelve different boulders located in topographically high positions with respect to the surroundings within the deposits were sampled for dating with cosmogenic ${ }^{36} \mathrm{Cl}$. For boulders VB13 (VB13a, VB13b) and VB14 (VB5 same boulder as VB14) two samples were taken. Samples were taken to cover the full extent of the deposit, from right near the source area to the distal sector.

For ${ }^{36} \mathrm{Cl}$ sample preparation we used the method of isotope dilution as described by Ivy-Ochs et al. (2004). Total $\mathrm{Cl}$ and ${ }^{36} \mathrm{Cl}$ were determined at the ETH AMS facility of the Laboratory for Ion Beam Physics (LIP) with the $6 \mathrm{MV}$ tandem accelerator. The ${ }^{36} \mathrm{Cl} / \mathrm{Cl}$ ratios of the samples were normalised to the ETH internal standard K382/4N with a value of ${ }^{36} \mathrm{Cl} / \mathrm{Cl}=17.36 \times 10^{-12}$, which is calibrated against the primary ${ }^{36} \mathrm{Cl}$ standard KNSTD5000 (Christl et al., 2013; Vockenhuber et al., 2019). Full process chemistry blanks $\left(3.4 \times 10^{-15}\right)$ were subtracted from measured sample ratios. All 14 rock samples were processed. Only seven were measured successfully due to too high ${ }^{36} \mathrm{~S}$, also in relation to the very low ${ }^{36} \mathrm{Cl}$ concentrations in these samples. All measured data are presented here. Major and trace element concentrations were determined with X-ray fluorescence (XRF) (Sect. S3) and inductively coupled plasma mass spectrometry (ICP-MS) (Sect. S4), respectively. We calculated surface exposure ages with the LIP ETH in-house MATLAB code based on the parameters presented in detail in Alfimov and Ivy-Ochs (2009, and references therein). A production rate of $54.0 \pm 3.5{ }^{36} \mathrm{Cl}$ atoms $(\mathrm{g} \mathrm{Ca})^{-1} \mathrm{yr}^{-1}$, which encompasses a muon contribution at the rock surface of $9.6 \%$, and a value of $760 \pm 150$ neutrons ( $\mathrm{g}$ air) ${ }^{-1} \mathrm{yr}^{-1}$ were found. These 


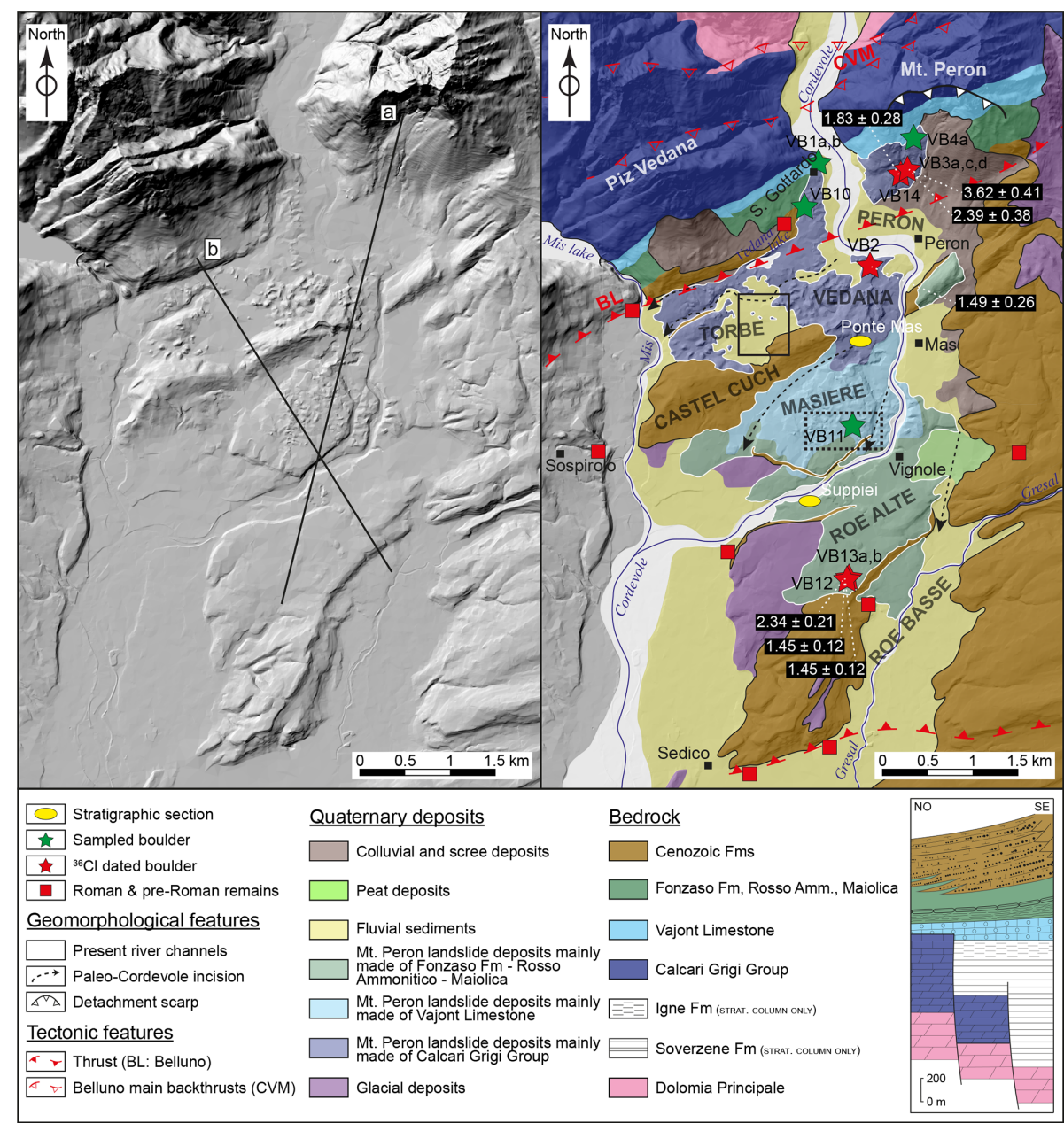

Figure 3. Geological map of the study area, based on our own field surveys and previous studies (Pellegrini, 2000; Pellegrini and Caneve, 2005), overlying a $5 \mathrm{~m}$ cell DTM (open data released by Regione Veneto: http://idt.regione.veneto.it/app/metacatalog/, last access: 17 October 2019). The boundary of Mt. Peron rock avalanche deposits is marked with a solid white line, whilst the contact between Quaternary sediments and bedrock is shown with a solid black line. The locations of boulders sampled for dating (red stars) and/or thin-section analysis (green stars) are shown. Obtained ${ }^{36} \mathrm{Cl}$ exposure ages are in kiloannum. Sites of Roman and pre-Roman archeological findings are indicated by red squares (from Capuis et al., 1988). Solid lines in the left frame correspond to the traces of the stratigraphic profiles in Fig. 4. Location of stratigraphic sections (yellow ellipses; Fig. 5) and palaeo-Cordevole paths (black dashed arrows) are shown. The extent of Fig. 6 (dotted black box) and Fig. S4 (solid black box; Supplement) is indicated. In the lower right, a stratigraphic sketch of bedrock formations cropping out in the Belluno area is given (modified from Costa et al., 1996).

values are in excellent agreement with production rates recently published by Marrero et al. (2016). Production from all major elements and through low-energy neutron capture in light of the trace elements (Table S4a) was fully considered. Production rates were scaled to the latitude, longitude and altitude of the sites based on Stone (2000). No correction was made for karst weathering of the boulder surfaces (see Styllas et al., 2018). The extent of karst dissolution on the boulder surfaces varies significantly from boulder to boulder. Implementing a rate of $5 \mathrm{~mm} \mathrm{ka}^{-1}$ would change the ages by less than $4 \%$, which does not affect any of the conclusions drawn here. Stated errors of the exposure ages (Table 1) include both analytical uncertainties and those of the pro- duction rates (Alfimov and Ivy-Ochs, 2009). Two different surfaces of boulder 13 were analysed (VB13a, $1.45 \pm 0.12$; VB13b, $1.45 \pm 0.12 \mathrm{ka}$ ); the weighted mean of $1.45 \pm 0.08 \mathrm{ka}$ is used for further discussion.

\section{Results}

\subsection{Mt. Peron release area}

The Mt. Peron scarp is $700 \mathrm{~m}$ wide and $600 \mathrm{~m}$ high, S-toSW facing, and partially circular. No secondary scarps are present. Numerous faults and fractures are visible on the wall (Fig. 2b) and are grouped into five main discontinuity 


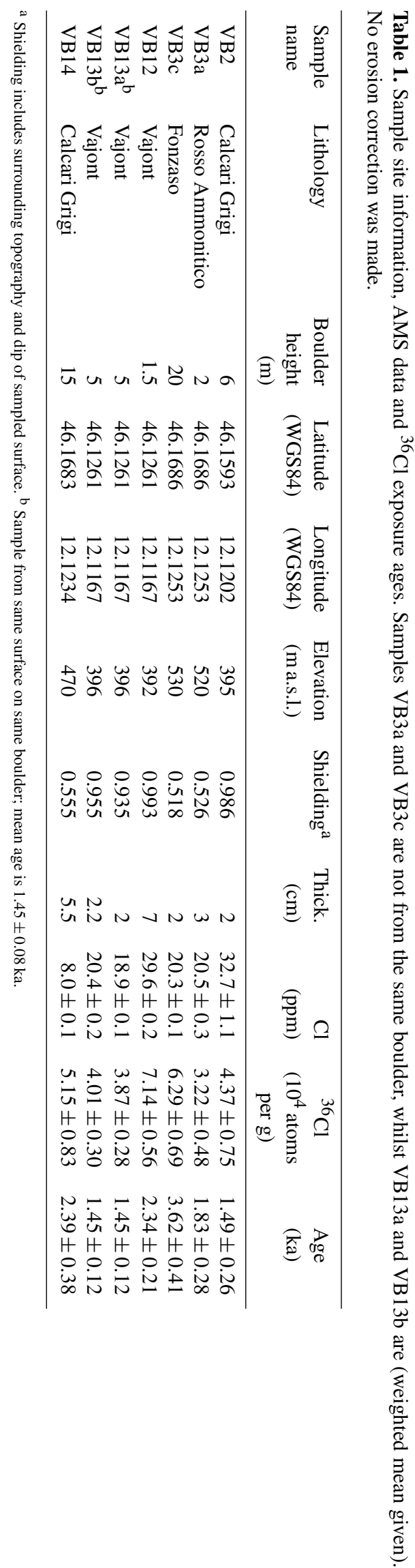

sets (Fig. 2c). These comprise (1) bedding, (2) WSW-ENEdirected frontal thrust planes, (3) NW-verging backthrustrelated planes, (4) NW-SE-aligned local conjugate fracture plane sets, and (5) persistent $\mathrm{N}-\mathrm{S}$-oriented planes interpreted as reactivated Jurassic faults (Masetti and Bianchin, 1987). Bedding is nearly vertical, and its orientation ranges from 146/78 to $170 / 80$ (dip direction/dip angle). The Belluno thrust, average orientation 337/64 (Costa et al., 1996), crops out at the base of the steep wall, whilst other Belluno thrust planes (295/53 to $340 / 67)$ were measured higher up along the wall (Fig. 2b). The NW-verging planes related to the backthrust are $111 / 15$ to $175 / 54$ and steepen to $80^{\circ}$ at higher elevations along the wall. The NW-SE-aligned fractures are 209/16 to 245/32 with an associated conjugate set, from $20 / 44$ to $62 / 30$, and nearly vertical fractures with a dip direction of 219 to 255 . The N-S-striking fracture planes dip both to the east (75/40 to 83/75) and to the west (240/71 to $299 / 18$ ). Today a myriad of large and small individual rock prisms bounded by these discontinuities are present in the upper part of the release area.

\subsection{Masiere di Vedana rock avalanche deposit}

The deposit covers an area of $\sim 9 \mathrm{~km}^{2}$ from the base of Mt. Peron southwards to Roe Basse $(\sim 5 \mathrm{~km})$ and westwards to Mis River ( $3 \mathrm{~km}$; Fig. 3). By means of open sections, the thickness of the deposit is estimated $\sim 10 \mathrm{~m}$ in the proximal area (near boulder VB2, Fig. 3), $\sim 15 \mathrm{~m}$ in the central sector near Torbe, $>30 \mathrm{~m}$ near the boundary between the Vedana and Masiere sectors (Ponte Mas section, Fig. 4 ), $\sim 5 \mathrm{~m}$ in the Masiere central sector, and $\sim 15 \mathrm{~m}$ in the southern (distal) sector (Suppiei section, Fig. 4). Using a mean thickness of $20 \mathrm{~m}$, a rough estimation of the total debris volume of $\sim 170 \mathrm{Mm}^{3}$ is obtained. Such a volume corresponds to a released rock mass of about $130 \mathrm{Mm}^{3}$ (bulking coefficient of $25 \%$; see Genevois et al., 2006). With a vertical drop $(H)$ of about $1150 \mathrm{~m}$ (from the top of Mt. Peron: $1486 \mathrm{~m}$ a.s.l., to Roe Basse area: $\sim 340 \mathrm{~m}$ a.s.l.) and a travel distance $(L)$ of about $5900 \mathrm{~m}$ (Fig. 3), we calculate an $H / L$ ratio of $\sim 0.2$ (Fahrböschung angle of $11^{\circ}$ ). Based on spatial pattern, boulder lithology and morphological character, we distinguish five sectors of the deposit: Peron, Vedana, Torbe, Masiere and Roe (Roe Alte and Roe Basse).

The Peron sector includes the talus apron deposits at the foot of Mt. Peron, the rock avalanche deposits on the east side of the river and the terrace of the town of Peron (at about $380 \mathrm{~m}$ a.s.l.). Boulders at the foot of the slope range up to $20 \mathrm{~m}$ in diameter (Fig. 5a). Three boulders in the Peron sector were dated with cosmogenic ${ }^{36} \mathrm{Cl}$ (Fig. 3; Table 1): VB3a (Rosso Ammonitico; $1.83 \pm 0.28 \mathrm{ka}$ ), VB3c (Fonzaso Fm.; $3.62 \pm 0.41 \mathrm{ka}$ ) and VB14a (Calcari Grigi Group; $2.39 \pm$ $0.39 \mathrm{ka}$ ). Based on the trend of all obtained ages, the age of VB3c is interpreted as an outlier, its age possibly reflecting the presence of inherited ${ }^{36} \mathrm{Cl}$ due to pre-exposure. The town of Peron lies on a terrace made of rounded gravel layers 


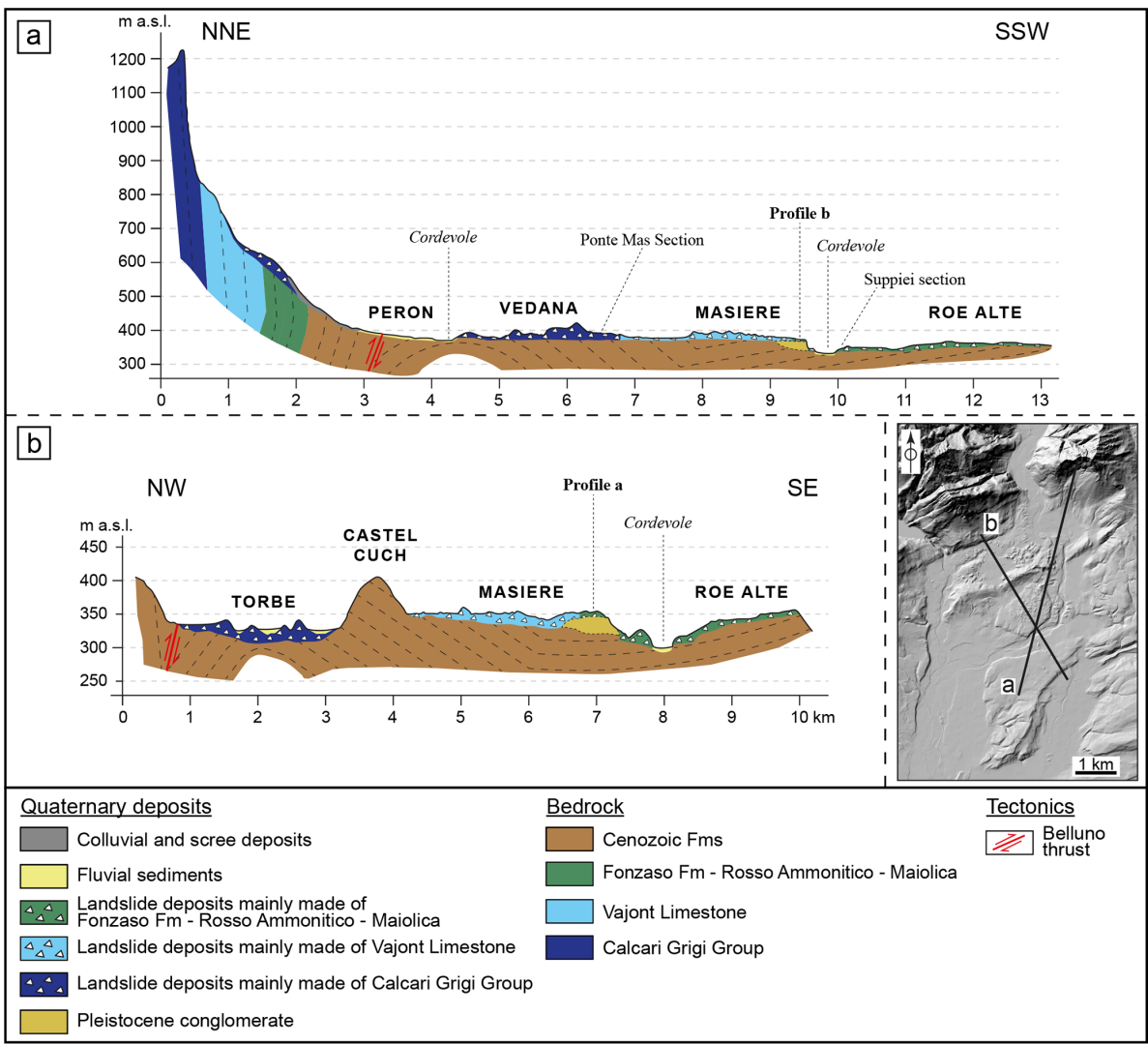

Figure 4. Geologic profiles of the Mt. Peron rock avalanche deposits (modified from Costa et al., 1996). Traces of the profiles are shown in the small DTM and in Fig. 3a, their extent being equal. The discussed sectors of the Mt. Peron rock avalanche, Vedana, Torbe, Masiere and Roe Alte, are indicated, along with the location of Ponte Mas and Suppiei stratigraphic sections (Fig. 5g and h). The vertical bedding and interpreted Belluno thrust are shown schematically. Note the preservation of bedrock stratigraphic order in the rock avalanche deposits from older to younger, i.e. from proximal to distal: Calcari Grigi Group, Vajont Limestone, Fonzaso Formation-Rosso Ammonitico-Maiolica.

with rare sand lenses that are interfingered with talus deposits (Caneve, 1985).

In the Vedana sector, the rock avalanche deposit displays an irregular forested topography with relief on the order of tens of metres (Fig. 5b). Huge blocks hundreds of cubic metres in size, mostly made of Calcari Grigi, dominate the carapace. This covers the main body of the deposit made of shattered rocks, which is comprised of very angular clasts (up to tens of centimetres in diameter) in a matrix of silty sand. The VB2 boulder (Calcari Grigi) gave an age of $1.49 \pm 0.26 \mathrm{ka}$; it lies on top of an $\sim 10 \mathrm{~m}$ thick sequence of rock avalanche deposits. In the Ponte Mas quarry (Figs. 3 and 5g), an open section showed glacial till (up to $3 \mathrm{~m}$ thick) incorporated into the base of the rock avalanche deposit; its original bedding is completely obliterated. This sediment is $>30 \mathrm{~m}$ thick and is composed of sub-rounded clasts (up to $20 \mathrm{~cm}$ in length), some of them striated, supported by a silty clay matrix. Clasts are sedimentary and volcanic, reflecting the catchment of the Cordevole palaeoglacier (see Pellegrini et al., 2006). Several ENE-WSW-trending incisions cut through the Vedana and Torbe sectors (main ones highlighted in Fig. 3). Irregular patches of sandy-silty and fine gravel sediments are found in the Vedana low-lying areas between the blocky reliefs.

The Torbe sector encompasses the distal northern lobe of the rock avalanche, characterised by 10 to $20 \mathrm{~m}$ high isolated hills and hummocks (Fig. 5d) that emerge from a flat topography. They are roughly aligned ENE-WSW, are circular at the base and have slope angles of 35-40 ${ }^{\circ}$. They are made of very angular Calcari Grigi boulders and clasts, with many jigsaw puzzle structures in a sandy, gravelly matrix (Fig. 5e). Such morphological structures are "toma" (Turnau, 1906; Abele, 1974; More and Wolkersdorfer, 2019). They are found in association with some large rockslides and are mainly made of landslide material, in many cases showing a gradation from very comminuted fragments in the outer part to less fractured material at the core (see von Poschinger and Ruegg, 2012; More and Wolkersdorfer, 2019). Six cores taken in the flat area between the hills (see Fig. 3 and Sect. S2) show up to $2 \mathrm{~m}$ of silty sand above the rock avalanche becoming more fine upwards. Torbe is crossed by the largest incision of the whole Masiere di Vedana (Fig. 3), ENE-WSW trending, $\sim 50 \mathrm{~m}$ wide and up to $20 \mathrm{~m}$ deep with respect to the 

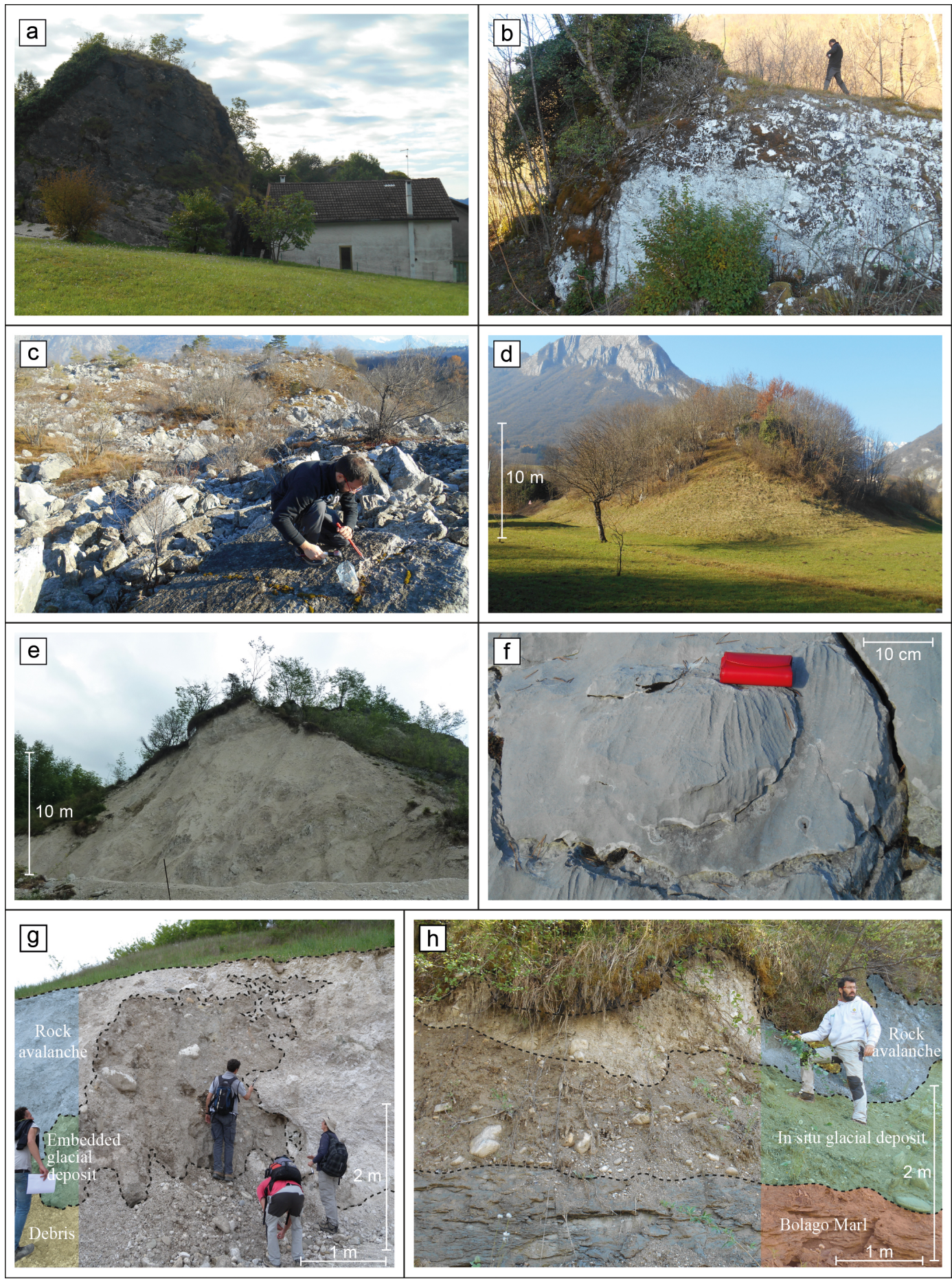

Figure 5. Photos of the deposits (a decametric boulder, Peron alluvial terrace; b plurimetric boulder, Vedana sector; c metric boulders, Masiere sector; $\mathbf{d}$ toma relief in the Torbe sector; e open section of a toma, Torbe sector; $\mathbf{f}$ karst evidence on a boulder, Masiere sector) and stratigraphic sections described in the text (g Ponte Mas section: incorporation of the underlying glacial deposit (green) into the rock avalanche deposit (light blue) is shown; h Suppiei section: glacial sediments (green), covered by rock avalanche deposit (light blue), rest directly on bedrock (red); locations in Figs. 3 and 4). 


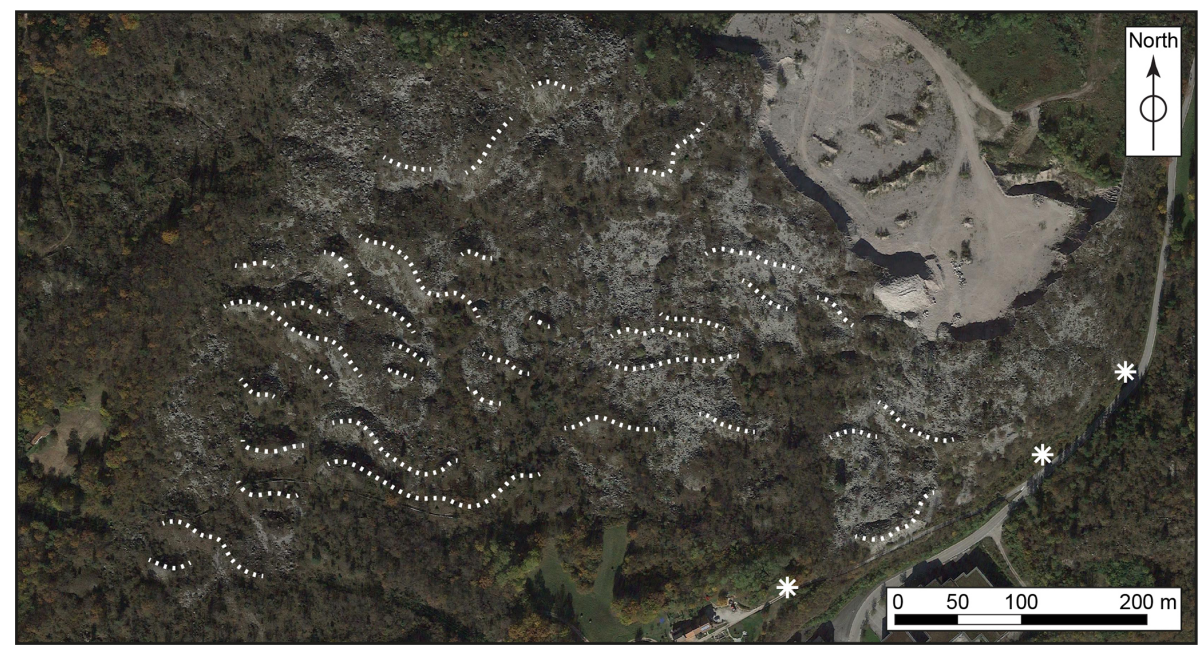

Figure 6. Transverse ridges in the southwestern part of the Masiere sector (basemap source: () Google Earth). Location of image shown in Fig. 3. The rock avalanche moved (from north to south) over a slight topographic high made up of Pleistocene conglomerate (see Fig. 4); the ridges are interpreted as compressional. White stars indicate locations where the contact between the rock avalanche and the conglomerate is exposed.

mean topographic surface. Cenozoic lithologies crop out at the base of this incision, with the rock avalanche deposit being $\sim 15 \mathrm{~m}$ thick. A shallower incision, a few metres deep, is located at the base of the Piz Vedana slope, still conveying a small amount of water coming from the Vedana Lake.

The Masiere sector is strikingly different from Vedana and Torbe. It is a bleak, vegetation-free, desert-like sea of limestone blocks, mainly of dolomitised Vajont Limestone (Fig. 5c). Boulders up to $3 \mathrm{~m}$ in diameter and abundant angular and sub-angular clasts, with almost no matrix, are present in the surficial part. In the southern part of Masiere, numerous 2-3 m high and up to $150 \mathrm{~m}$ long ridges, aligned roughly $\mathrm{E}-\mathrm{W}$, are present (Fig. 6). The contact of the rock avalanche with the underlying Pleistocene conglomerate crops out near the southern boundary of the Masiere (white asterisks in Fig. 6), where the deposit is only $\sim 5 \mathrm{~m}$ thick. Next to the northern boundary of Masiere, the Cordevole River flows upon the Cenozoic rocks of the Castel Cuch ridge, covered elsewhere by the rock avalanche. An ENE-WSW-trending shallow incision (Fig. 3) with associated well-sorted, medium-to coarse-grained sandy deposits is present, almost parallel to Castel Cuch. A roughly $\mathrm{N}-\mathrm{S}$ trending incision, a few metres deep, $\sim 10 \mathrm{~m}$ wide and about $500 \mathrm{~m}$ long, is located just to the west of the Cordevole River. The town of Mas is built upon a flat terrace, mainly made of sorted rounded gravels with a sandy matrix, that bounds the Masiere to the east.

Roe Alte and Roe Basse comprise the distal sector of the Masiere di Vedana to the south (Fig. 3), where there are angular clasts up to $20 \mathrm{~cm}$ in diameter and very few boulders immersed in a sandy matrix are scattered in the meadows. Boulders belong to the Fonzaso Formation, Rosso Ammonitico and Maiolica, with very few of them made of Vajont Lime- stone. Roe Basse is made of silty/sandy alluvial sediments deposited by the Gresal and other minor streams coming from the east, mantling the rock avalanche deposit on the northwestern side. The Suppiei section, $100 \mathrm{~m}$ long and $25 \mathrm{~m}$ high, on the left flank of the Cordevole River (Figs. 3 and 5h; Sect. 5), shows the Bolago Marl unconformably overlain by $0.5-2 \mathrm{~m}$ of glacial till. This is in turn covered, with a sharp and undulated contact, by up to $20 \mathrm{~m}$ of rock avalanche debris decimetric in size, with boulders ( $\sim 1 \mathrm{~m}$ diameter) on top. On the Roe Alte rocky upland, the rock avalanche is at most $2 \mathrm{~m}$ thick, with rare boulders (1-2 $\mathrm{m}$ diameter). Two boulders made of Vajont Limestone (Fig. 3) have been dated with ${ }^{36} \mathrm{Cl}$ (VB12, $2.35 \pm 0.21 \mathrm{ka}$; VB13, $1.45 \pm 0.08 \mathrm{ka}$; Table 1). South of the town of Mas, the Cordevole River flows into narrow meanders entrenched $\sim 20 \mathrm{~m}$ into rock avalanche deposits, alluvial material, glacial sediments and bedrock. The terrace of the Vignole village is almost totally made of rock avalanche debris, despite being remarkably flat.

\section{Interpretation and discussion}

\subsection{Age of the Mt. Peron rock avalanche}

${ }^{36} \mathrm{Cl}$ surface exposure ages from boulders all across the deposit range from $1.45 \pm 0.08$ to $2.39 \pm 0.38 \mathrm{ka}$ (Table 1). All ages show a good overlap within uncertainties. A single sample (VB3c) gave a result markedly different from the others: $3.62 \pm 0.41 \mathrm{ka}$. Although this age may point to preexposure of the sampled boulder surface (see Sewell et al., 2006; Merchel et al., 2013), as for example seen at Lavini di Marco (Martin et al., 2014), the possibility exists that this boulder is part of a partially buried older deposit located right 
at the foot of Mt. Peron. The poorly developed karst dissolution features $(0.5-1 \mathrm{~cm}$ deep karren) on the tops of many boulders suggest as well that the deposit is relatively young. The average of ${ }^{36} \mathrm{Cl}$ ages, excluding VB3c as an outlier, is $1.90 \pm 0.45 \mathrm{ka}$. The uncertainty of the mean is based on the cumulative probability of uncertainties for all samples based on a Gaussian probability distribution (one sigma level). Such a value indicates that the rock avalanche, considering the error range, occurred during historical times, between $340 \mathrm{BCE}$ and $560 \mathrm{CE}$. These results are in stark contrast to previous reconstructions, which pointed to a late glacial age (Mazzuoli, 1875; Hoernes, 1892; Squinabol, 1902; Dal Piaz, 1912; Venzo, 1939; Genevois et al., 2006; Pellegrini et al., 2006). The dates 1113,1114 , and $1117 \mathrm{CE}$ proposed for the main landslide event suggested by some authors (Piloni, 1607; Miari, 1830) may be associated with the Verona earthquake at $1117 \mathrm{CE}$. That event was clearly felt in the Belluno area, inducing numerous landslides (Guidoboni et al., 2005), but its age is not consistent with the cosmogenic dates on the Masiere di Vedana. To search for independent constraints for the age of the main landslide event, detailed research in numerous archives and chronicles was undertaken. This area during Roman time was largely and uniformly inhabited by "incolae" for agricultural aims, being the area located next to the Claudia Augusta Altinate road connecting Feltre with Belluno (Fig. 1) (Alpago-Novello, 1957, 1988). The presence of a Roman bridge crossing the Cordevole River north of Mt. Peron indicates there was a connection to the main Claudia Augusta Altinate road. While numerous Neolithic and Roman archeological sites are reported around the Masiere di Vedana (Capuis et al., 1988; Frassine et al., 2016), no Roman or pre-Roman archaeological remains have been found within the rock avalanche deposits (Fig. 3). If the Masiere di Vedana deposit was settled after Roman times, previous settlements eventually located in the area would have been buried by the event. The oldest record for the post-event human presence is a hospice built in the 12th century CE (1155 CE; Magoga and Marin, 1998) on the fluvial terrace near the village of S. Gottardo (Fig. 3). Therefore, historical data indicate a time frame between late Roman times and the early Middle Ages.

The age uncertainties do not allow us to directly determine if the Masiere di Vedana deposit was due to a single failure or multiple events. The distribution of the available dates has no spatial pattern across the deposit, no physical boundaries occur and no buried soil layers have been found within the deposits. Moreover, the volume and $H / L$ ratio of the landslide (see Sect. 5.2 for further discussion), together with the morphology of the scarp and the absence of secondary scarps, indicate a single huge catastrophic event. Therefore, a single rock avalanche occurred in historical time, contradicting previous interpretations (e.g. Genevois et al., 2006; Pellegrini et al., 2006). Such a young age implies that glacial unloading was not responsible for the destabilisation of the southern side of Mt. Peron and makes a re-evaluation of the involved driving factors and potential triggers necessary.

\subsection{Release, emplacement and post-event modification of the deposit}

A schematic reconstruction of the reach of the Cordevole Valley involved in the rock avalanche can be depicted before, during and after the event. Before the rock avalanche, the Cordevole River flowed through a gentle rolling landscape along the foot of Piz Vedana and through a breach cutting the Castel Cuch bedrock ridge just north of the village of Mas (Figs. 3 and 7a). Topographic highs, like Castel Cuch and Roe Alte, were at that time mantled with glacial sediments attributable to the last glaciation.

The rock avalanche involved the detachment of about $130 \mathrm{Mm}^{3}$ from the southern face of Mt. Peron. Initial movement was sliding along the NW-verging backthrustrelated planes (Fig. 2). En bloc movement may have been only briefly sustained as the pervasive network of fractures favoured a massive collapse. The rock mass immediately evolved into a rock avalanche whose volume increased by fragmentation up to $170 \mathrm{Mm}^{3}$ and spread out onto the flat plain below. The $H / L$ ratio of $\sim 0.2$ (apparent friction angle of $11^{\circ}$ ) and comparison with empirical and modelling plots of $H / L$ vs. volume (e.g. Spreafico et al., 2018; Aaron and McDougall, 2019) mark the Mt. Peron event as extremely mobile. As a basis for comparison, the Fernpass rock avalanche has a $H / L$ of 0.9 , a volume of $1 \mathrm{~km}^{3}$ and a significantly longer runout distance of $15.5 \mathrm{~km}$ (Prager et al., 2009). It may be possible to glean information about the failure style from the distribution of boulder lithologies, which follows the stratigraphic order of the bedrock exposed in the source area. This has also been noted at the Tschirgant rock avalanche deposits in Austria (Dufresne et al., 2016) and the Frank slide in Canada (Charrière et al., 2016). In the Mt. Peron bedrock, the lithologic sequence from west to east is Calcari Grigi Group, Vajont Limestone, Fonzaso Fm., Rosso Ammonitico and Maiolica. This pattern is mirrored in the deposits (Figs. 3 and 4): Vedana and Torbe are dominated by Calcari Grigi Group, Masiere by Vajont Limestone, and Roe by Fonzaso Fm., Rosso Ammonitico and Maiolica. Experiments and modelling suggest that this kind of zonation is likely to occur when the sliding mass propagates as a flexible sheet, with laminar flow (Friedmann et al., 2006).

Several landforms within the Masiere di Vedana provide further clues on the processes of propagation and emplacement. The tomas in the Torbe sector suggest differential velocities in the moving mass propagating on a water-saturated substrate (Strom, 2006; Prager et al., 2009; Dufresne, 2012; Dufresne et al., 2016; Aaron et al., 2017). Tomas, with likely similar origin, are present in the distal deposits at Fernpass in Tyrol (Prager et al., 2009) and at Flims (von Poschinger and Ruegg, 2012). Recently, More and Wolkersdorfer (2019) proposed for the toma hills at Fernpass an alternative ori- 


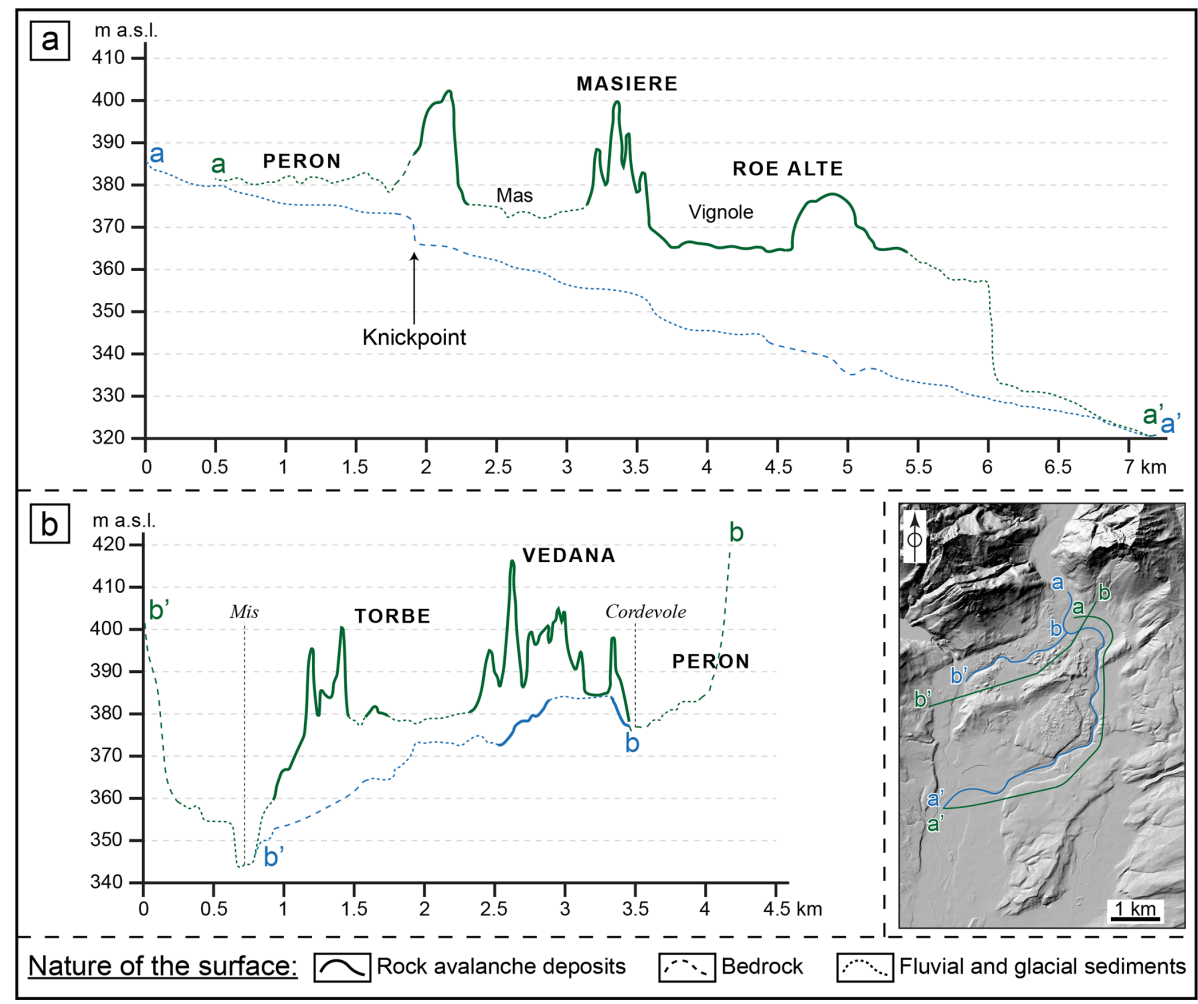

Figure 7. Curvilinear topographic profiles $(10 \times$ vertical exaggeration $)$ showing the relationship between the bigger incisions and the external main surfaces related to the rock avalanche and the post-event evolution. Profiles correspond to the present course of Cordevole creek (blue line in a) paired with the main topographic surfaces on its left bank (green line in a) and the main incision passing through the Torbe and Vedana sectors (blue line in b) paired with the main topographic surfaces on its left side (green line in b). Traces of the profiles are shown in the small DTM (open data released by Regione Veneto: http://idt.regione.veneto.it/app/metacatalog/, last access: 17 October 2019), which corresponds to Fig. 3.

gin from internal erosion by suffusion. However, at Masiere di Vedana the fluvial deposition above the rock avalanche suggests that the suffusion process can be ruled out. In contrast to the increased mobility seen in the Torbe sector, in the central Masiere area, landforms indicative of stalling are present (Fig. 6). The stacked subparallel transverse ridges, much like those noted at Tschirgant (Patzelt, 2012; Dufresne et al., 2016; Ostermann et al., 2017), with slight overrunning of the ridges in front by those behind, indicate slowing down of the moving mass due to longitudinal compression (Nicoletti and Sorriso-Valvo, 1991; Dunning et al., 2005; Strom, 2006; Dufresne et al., 2016). Outcrop relationships (Fig. 6) suggest that the Pleistocene conglomerate inhibited the rock mass flow, in combination with the slight uphill gradient. The ridges at Masiere were previously interpreted as neotectonic lineaments by Baggio and Marcolongo (1984).

After the event, the Cordevole River changed its channel several times. The rock avalanche blocked the river, creating accommodation space to the north, where possibly a temporary lake formed. The river was then forced to flow westward across the deposit as indicated by the palaeochannels in the Vedana and Torbe sectors (black arrows, Fig. 3), taking dif- ferent paths at different times. Low-lying areas were progressively filled, as shown by the sequence recorded in core TB1 becoming more fine upwards (Fig. S2a). The Torbe, Vedana and Peron terraces are flat surfaces at $\sim 380 \mathrm{~m}$ a.s.l. (Fig. $7 \mathrm{~b}$ ). Afterwards, a further sedimentation was hindered by the trenching in Torbe. The Cordevole River finally breached the landslide deposit to the southeast, through the Castel Cuch ridge made of Cenozoic rocks (Fig. 3). The river initially flowed from Mas (about $375 \mathrm{~m}$ a.s.l.; green line in Fig. 7a) to the southern flank of Castel Cuch as suggested by the still recognisable palaeochannel (Fig. 3) filled with wellsorted, medium- to coarse-grained sand (Caneve, 1985). Subsequently, the Cordevole moved to the eastern side of the Pleistocene conglomerate cliff (Fig. 3). The final diversion of the river formed the Peron, Mas and Vignole terraces and currently flows some metres below with upstream migration of the knickpoint (Fig. 7).

\subsection{Driving factors and potential hazard}

In the Cordevole and Piave valleys many landslides have been recorded (Fig. 8) and have caused a great deal of damage and casualties (Rossato et al., 2018). Rock avalanches 
such as Masiere di Vedana are difficult to predict (Hungr, 2006) and may be very destructive due to their huge volume and extreme runout (Guzzetti, 2000; Hungr, 2004; Geertsema et al., 2006; Evans et al., 2007; Sosio et al., 2008; Cui et al., 2011; Hermanns and Longva, 2012). In light of the results we obtained, the search for the drivers of the Masiere di Vedana rock avalanche is both timely and imperative. Even if what determines the moment of failure may be difficult to pinpoint, increased pore pressure and seismic ground shaking are the primary candidates in such cases (Wieczorek, 1996; Schuster and Wieczorek, 2002; Takahashi, 2001). However, rock avalanches may start without a definite external trigger, the progressive accumulation of rock fatigue being enough to overcome the resisting forces of the rock mass. This is the case, for example, of the Tsatichhu landslide (10 September 2003) in Bhutan (Dunning et al., 2006) and the several Randa events (total of $30 \mathrm{Mm}^{3}$ ) in 1991 in Switzerland (Loew et al., 2012; Stead and Eberhardt, 2013).

The Belluno area has high mean annual rainfall $(1643 \mathrm{~mm}$ in the time interval 1994-2018 at https://www.arpa.veneto.it/ dati-ambientali/open-data, last access: September 2019) and is prone to extreme rainfall events (e.g. $>300 \mathrm{~mm}$ of rain at Sospirolo during a single event: 27 October-1 November 2018; ARPAV, 2018). Moreover, at the time of the Masiere di Vedana rock avalanche, between late Roman times and the early Middle Ages, the southeastern Alps and northeastern Italy were affected by various periods of climate degradation during which several extreme meteorological events occurred (Wirth et al., 2013; Rossato et al., 2015). One of these extreme events had an impact all over Europe between 50 and $250 \mathrm{CE}$, with marked intensity and widespread flooding recognisable in the stratigraphic records (Macklin et al., 2006; Benito et al., 2015; Rossato et al., 2015; Cremonini et al., 2013). This period of severe rainfall could possibly have been the trigger for the Masiere di Vedana rock avalanche or at least may have acted as a driving and destabilising factor. Likewise, the 1987 Val Pola rock avalanche in the central Alps was triggered by a period of exceptional rainfall (Crosta et al., 2004).

The Veneto region is prone to earthquake activity, and the study area is categorised as level 2 seismic hazard ("possible strong earthquakes" in Ordinanza del PCM n. 3519/2006), as the historical record testifies (up to $\sim M_{\mathrm{w}}=6.5$; Viganò et al., 2013, 2015; Rovida et al., 2016). Continuous instrumental monitoring of the Belluno area dates back only to 1977 (Sandron et al., 2014). Preceding catalogued major seismic events in the region are based on either historical chronicles, dated building damage and/or observed rockfalls (Piloni, 1607; Taramelli, 1883; Guidoboni et al., 2005, 2018). Within a radius of $30 \mathrm{~km}$ from Mt. Peron, eight earthquakes with $M_{\mathrm{w}}$ greater than 5.0, and one exceeding 6.0, were recorded (Fig. 1). The strongest $\left(M_{\mathrm{w}}=6.3\right)$ occurred just $20 \mathrm{~km}$ to the east of Mt. Peron on 29 June 1873 (Rovida et al., 2016, and references therein). Severe damage to Belluno

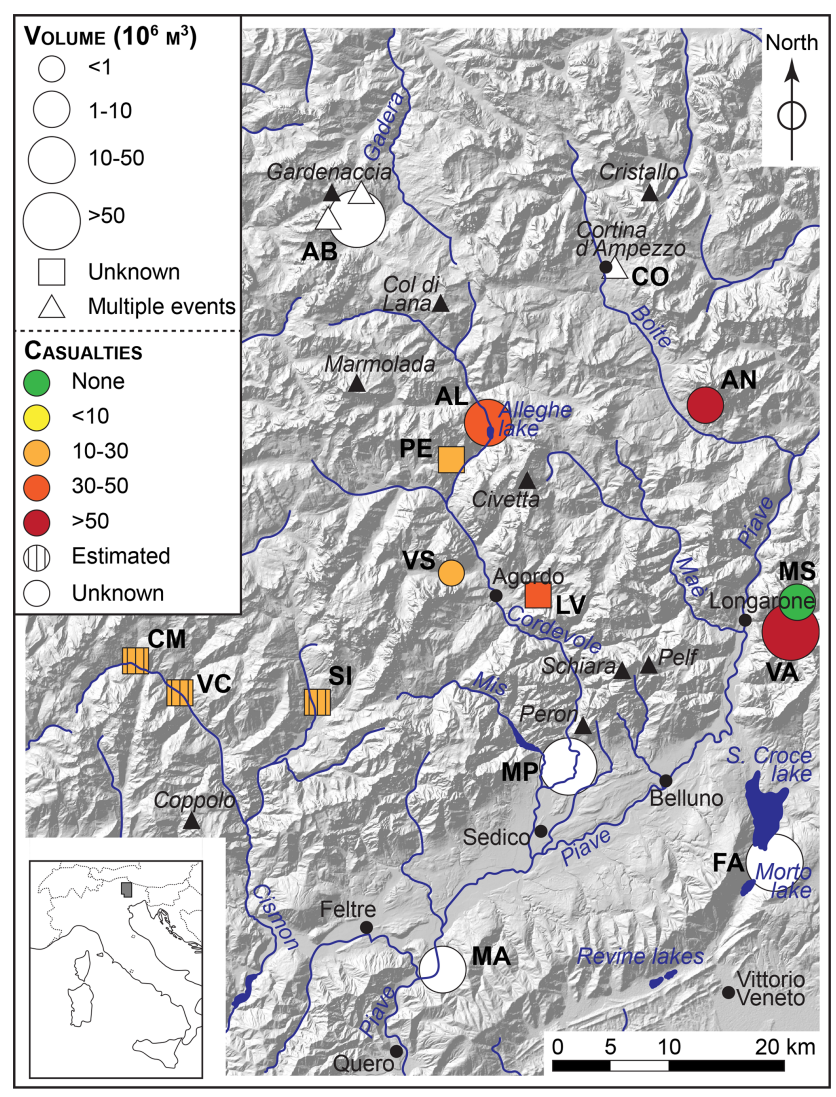

Figure 8. Largest and most damaging (in terms of human lives) landslides located near Mt. Peron (base map is a SRTMderived digital elevation model with $30 \mathrm{~m}$ cells; source: http: //viewfinderpanoramas.org/, last access: 17 October 2019). Volumes of deposits correspond to the size of the symbols; casualties are shown with colour coding. AB: Alta Badia, several events between $11500 \mathrm{BCE}$ and present (Borgatti et al., 2004); AL: Alleghe, $1771 \mathrm{CE}$ (Ermini and Casagli, 2003); AN: Antelao, 1814 CE (Montandon, 1933); CM: Col Mandro, 1825 CE (Montandon, 1933); CO: Cortina d'Ampezzo, several events between 10700 and 2000 BCE (Borgatti and Soldati, 2010); FA: Fadalto, late glacial to present (Pellegrini and Surian, 1996); LV: La Valle, 1701 CE (Montandon, 1933); MA: Marziai, 17 500-15000 BCE (Pellegrini et al., 2006); MS: Mt. Salta, 1674 CE (Montandon, 1933); PE: Pecol, 1841 CE (Montandon, 1933); MP: Mt. Peron, late Roman times - early Middle Ages (this work); SI: Siror, 1348 CE (Montandon, 1933); VA: Vajont, 1963 CE (Borgatti et al., 2004); VC: Val Cia, 1882 CE (Montandon, 1933); VS: Valle San Lucano, 1908 CE (Aldighieri et al., 2016).

city was reported during the Asolo (25 February $1695 \mathrm{CE}$; $M_{\mathrm{w}}=6.4$ ), Friuli (6 May $1976 \mathrm{CE} ; M_{\mathrm{w}}=6.5$ ) and Verona (3 January $1117 \mathrm{CE} ; M_{\mathrm{w}}=6.5$ ) earthquakes whose epicentres were located, respectively, 60, 65 and $140 \mathrm{~km}$ away (Guidoboni et al., 2018). As for the time frame suggested by our chronology, historical records report an important seismic event in July $365 \mathrm{CE}$ that resulted in damage to the city of Belluno (Piloni, 1607). These data suggest that the Bel- 
luno area is sensitive to seismic shakings originating even hundreds of kilometres away. Galadini et al. (2005) discuss evidence that active tectonics plays a key role in the reported intensification of slope instability registered in this area during the last 1500 years. The most important effect of the frequent seismic activity is the progressive increase in the rock fatigue, with the formation of failure surfaces and the removal of rock bridges and roughness on discontinuity planes (Friedmann et al., 2003; Brideau et al., 2009; Parker et al., 2013; Stead and Eberhardt, 2013; Preisig et al., 2015; Gischig et al., 2016). Earthquakes have been suggested as triggers for several Alpine rock avalanches (e.g. Prager et al., 2009; Grämiger et al., 2016; Ivy-Ochs et al., 2017; Köpfli et al., 2018) and are known to have caused several rockfalls in the Belluno area (e.g. Piloni, 1607; Miari, 1830; Guidoboni et al., 2005). Moreover, they are considered to be a possible trigger for failure of some pillars located on the southern side of Mt. Peron (Di Giusto, 2012).

The predisposition of the southwest Mt. Peron face to failure is attributable to the structural setting and the regionalscale framework. The entire Belluno Dolomites have experienced a long deformation history since the Miocene (Doglioni, 1990), related to regional-scale stress connected to the anticlockwise rotation of the Adria plate, indented with the Alpine orogeny (Márton et al., 2003; D'Agostino et al., 2008). The thrusts and backthrusts (WSW-ENE oriented) that encase Mt. Peron relate to this phase of activity, also creating the two conjugate fracture sets (NW-SE oriented) and inducing the reactivation of the Jurassic faults (N-S oriented) and the overturning of the beds. The area between the Belluno thrust to the south, the Val Carpenada - Val di Vido - Val Madonuta backthrust to the north, the Caorame Valley to the west and the Piave Valley to the east (Fig. 1) is structurally homogeneous and characterised by the same fracture sets identified at Mt. Peron (Bosellini et al., 1981; Masetti and Bianchin, 1987; Bigi et al., 1990; Costa et al., 1996). In limestones, where these intersect, rock dissolution and caves can form (Filipponi et al., 2009; Sauro et al., 2013), further weakening the rock (Pánek et al., 2009; Gutierrez et al., 2014). The Mt. Peron southern wall is known locally as the "weeping rock" due to the numerous caves and karst springs along the steep rock face (Fig. 2b).

Our dating of the Masiere di Vedana landslide to late Roman times casts considerable doubt on the previous late glacial chronological assessment (e.g. Pellegrini et al., 2006). Consequently, stress release following downwasting of the Last Glacial Maximum (LGM) Piave glacier, which had been previously considered the main driver of the rock avalanche, actually played no direct role in the process. Climatic and tectonic factors were much more important. In addition, the classification of the deposits as late glacial led to underplaying of the possible hazard at Mt. Peron. The situation at Mt. Peron, with steeply dipping-to-overturned bedding in a limestone massif crisscrossed by numerous faults and riddled with karst fissures, is presently the same that produced the massive failure of the Masiere di Vedana. Several-hundredmetre-high rock prisms along the top of the headscarp are partially detached along the discussed fracture systems and loom perilously over the inhabited valley below (Di Giusto, 2012). Our results suggest the need for a reconsideration of the hazard related to not only the southern Mt. Peron face, as the rock slopes still present evident structural weakness, but also the whole area lying between the Belluno thrust and its backthrusts, as intense rainfall and earthquakes can occur at any time.

\section{Conclusions}

Data acquired in this study provide a new contribution to the knowledge of the timing, failure and propagation of the Masiere di Vedana rock avalanche. The rock avalanche $\left(\sim 130 \mathrm{Mm}^{3}\right)$ detached from the southern slope of Mt. Peron. The deposit extends over an area of $9 \mathrm{~km}^{2}$, with a total volume of $\sim 170 \mathrm{Mm}^{3}$. A $H / L$ ratio $\sim 0.2$ is calculated, marking it as extremely mobile, which is also shown by the maximum runout of $6 \mathrm{~km}$. Geomorphological, stratigraphic and historical evidence when combined with cosmogenic ${ }^{36} \mathrm{Cl}$ exposure ages, mean age $1.90 \pm 0.45 \mathrm{ka}$, point to a single event that occurred in or after late Roman times but before the early Middle Ages.

The steep rock wall on the south face of Mt. Peron shows a pervasive deformation; numerous fractures and faults crosscut the sub-vertical to slightly overturned carbonate Mesozoic bedrock. The WSW-ENE-directed backthrust planes, which are the most continuous ones, constituted the planes along which the rock mass initially slid, rapidly breaking up and evolving into a rock avalanche.

The stratigraphic sequence is preserved in the rock avalanche deposit. Lithologies that presently constitute the western part of the source area were deposited in the proximal sectors (Vedana, Torbe), while the more easterly outcropping ones reached the distal areas (Masiere, Roe Alte). Landforms of the deposit suggest differential velocities during emplacement. In the NW sector (Torbe) enhanced mobility likely due to interaction with water-saturated path material is evidenced by the numerous ENE-WSW-aligned tomas. In contrast, in the middle sector (Masiere) stacked transverse ridges point to stalling, perhaps related to the gentle uphill gradient and impeded propagation over Pleistocene conglomerates. Post-event evolution comprises formation of backwater alluvial terraces and the wandering of the Cordevole River in the rock avalanche deposits, with incision and aggradation phases.

Identified pivotal drivers are the overall structural setting, exceptional rainfall events and seismic shakings. Their combination produced a pervasive fracturation and weathering of the rock mass, with progressive increase in rock fatigue. No exceptional event may actually be required for such rock 
avalanches to occur, as accumulation of damage markedly lowers the energy needed to trigger failure.

Considering the new data provided, we highlight that the same driving factors responsible for the Masiere di Vedana rock avalanche are still present today at Mt. Peron. The area between the Belluno thrust and its backthrusts and from the Caorame to the Piave valleys is structurally analogous to Mt. Peron, and therefore re-evaluation of the landslide hazard may be warranted. The possible occurrence of huge rock avalanches and minor rockfalls is a scenario that is necessary to take into consideration in future hazard evaluation and mapping.

Data availability. All data are in the paper or in the Supplement.

Supplement. The supplement related to this article is available online at: https://doi.org/10.5194/nhess-20-2157-2020-supplement.

Author contributions. All authors contributed to the discussion, field survey, data collection and improvement of the text, which has been written mostly by SR, SIO, SM and GM. Each author contributed to different parts, here listed: geomorphology: SR, SIO, GM, MDZ, NS, PM; geological and structural analysis: SM, AV, PC; remote sensing and GIS elaborations: SR; dating: SI, CV, SM; thin-section analysis: MR.

Competing interests. The authors declare that they have no conflict of interest.

Acknowledgements. The Ion Beam Physics group at ETH Zurich is thanked for support of fieldwork, laboratory work and AMS measurements. Andrea Cuman and Livio Ronchi are thanked for their support in the early phases of the research.

Financial support. This research has been supported by the Università degli Studi di Padova (grant no. Progetto di ricerca di Ateneo 2014, CPDA140511).

Review statement. This paper was edited by Paolo Tarolli and reviewed by two anonymous referees.

\section{References}

Aaron, J. and McDougall, S.: Rock avalanche mobility: The role of path material, Eng. Geol., 257, 105126, https://doi.org/10.1016/j.enggeo.2019.05.003, 2019.

Aaron, J., McDougall, S., Moore, J. R., Coe, J. A., and Hungr, O.: The role of initial coherence and path materials in the dynamics of three rock avalanche case histories, Geoenviron. Disast., 4, 5 , https://doi.org/10.1186/s40677-017-0070-4, 2017.

Abele, G.: Bergstürze in den Alpen. Ihre Verbreitung, Morphologie und Folgeerscheinungen, Wiss. Alpenvereinshefte 25, Deutscher Alpenverein, Munich, 1974.

Aldighieri, B., Testa, B., and Bertini, A.: 3D exploration of the San Lucano Valley: virtual geo-routes for everyone who would like to understand the landscape of the Dolomites, Geoheritage, 8, 77-90, https://doi.org/10.1007/s12371-015-0164-x, 2016.

Alfimov, V. and Ivy-Ochs, S.: How well do we understand production of ${ }^{36} \mathrm{Cl}$ in limestone and dolomite?, Quat. Geochronol., 4, 462-474, https://doi.org/10.1016/j.quageo.2009.08.005, 2009.

Alpago-Novello, L.: Resti di Centuriazione Romana nella Val Belluna, Atti Accad. Naz. Lin., 12, 5-6, 1957.

Alpago-Novello, L.: Aggiornamenti sulla centuriazione romana della Val Belluna, Bellunates, Catubrini, Feltrini, 267, 117-142, 1988.

ARPAV: Technical report on the 27/10/2018-01/11/2018 meteorological event, available at: https://www. regione.veneto.it/c/document_library/get_file?uuid= 094022ae-43e7-46b1-86d2-ff3ebf669b89\& groupId=90748 (last access: September 2019), 2018.

Baggio, P. and Marcolongo, B.: Contributo del telerilevamento alla conoscenza della sinclinale di Belluno. Il modello neotettonico derivato, in: Atti A.I.T.A.: Esperienze e Prospettive del telerilevamento, 9-11 May 1984, Bari, Italy, 707-736, 1984.

Benito, G., Macklin, M. G., Panin, A., Rossato, S., Fontana, A., Jones, A. F., Machado, M. J., Matlakhova, E., Mozzi, P., and Zielhofer, C.: Recurring flood distribution patterns related to short-term Holocene climatic variability, Sci. Rep.-UK, 5, 16398, https://doi.org/10.1038/srep16398, 2015.

Bigi, G., Cosentino, D., Parotto, M., Sartori, R., and Scandone, P.: Structural model of Italy, scale $1: 500,000, \mathrm{CNR}$, Progetto Finalizzato Geodinamica, Florence, Italy, 1990.

Blais-Stevens, A., Hermanns, R. L., and Jermyn, C.: A ${ }^{36} \mathrm{Cl}$ age determination for Mystery Creek rock avalanche and its implications in the context of hazard assessment, British Columbia, Canada, Landslides, 8, 407-416, https://doi.org/10.1007/s10346011-0261-0, 2011.

Borgatti, L. and Soldati, M.: Landslides as a geomorphological proxy for climate change: A record from the Dolomites (northern Italy), Geomorphology, 120, 56-64, https://doi.org/10.1016/j.geomorph.2009.09.015, 2010.

Borgatti, L., Soldati, M., Carton, A., Corsini, A., Galuppo, A., Ghinoi, A., Marchetti, M., Oddone, E., Panizza, M., Pasuto, A., Pellegrini, G. B., Schiavon, E., Siorpaes, C., Surian, N., and Tagliavini, F.: Geomorphology and slope instability in the Dolomites (Northern Italy): from Lateglacial to recent geomorphological evidence and engineering geological applications, Mem. Descr. Carta Geol. d'It., 63, 1-52, 2004.

Bosellini, A., Masetti, D., and Sarti, M.: A Jurassic "Tongue of the ocean" infilled with oolitic sands: the Belluno Trough, Venetian 
Alps, Italy, Mar. Geol., 44, 59-95, https://doi.org/10.1016/00253227(81)90113-4, 1981.

Bowman, E. T., Take, W. A., Rait, K. L., and Hann C.: Physical models of rock avalanche spreading behaviour with dynamic fragmentation, Can. Geotech. J., 49, 460-476, https://doi.org/10.1139/t2012-007, 2012.

Brideau, M. A., Yan, M., and Stead, D.: The role of tectonic damage and brittle rock fracture in the development of large rock slope failures, Geomorphology, 103, 30-49, https://doi.org/10.1016/j.geomorph.2008.04.010, 2009.

Caneve, L.: Geomorfologia delle "Marocche" di Vedana nel Vallone Bellunese, MS thesis, University of Padova, Padova, Italy, 1985.

Capuis, L., Leonardi, G., Pesavento Mattioli, S., and Rosada, G. (Eds.): Carta Archeologica del Veneto 1:100,000, Panini, Modena, 1988.

Charrière, M., Humair, F., Froese, C., Jaboyedoff, M., Pedrazzini, A., and Longchamp, C.: From the source area to the deposit: Collapse, fragmentation, and propagation of the Frank Slide, Geol. Soc. Am. Bull., 128, 332-351, https://doi.org/10.1130/B31243.1, 2016.

Christl, M., Vockenhuber, C., Kubik, P. W., Wacker, L., Lachner, J., Alfimov, V., and Synal, H. A.: The ETH Zurich AMS facilities: Performance parameters and reference materials, Nucl. Instrum. Meth. B, 294, 29-38, https://doi.org/10.1016/j.nimb.2012.03.004, 2013.

Costa, V., Doglioni, C., Grandesso, P., Masetti, D., Pellegrini, G. B., and Tracanella, E.: Note illustrative della Carta geologica d'Italia alla scala 1 : 50, 000: Foglio 063 - Belluno, Istituto Poligrafico e Zecca dello Stato, Rome, Italy, 1996.

Cremonini, S., Labate, D., and Curina, R.: The late-antiquity environmental crisis in Emilia region (Po river plain, Northern Italy): Geoarchaeological evidence and paleoclimatic considerations, Quatern. Int., 316, 162-178, https://doi.org/10.1016/j.quaint.2013.09.014, 2013.

Crosta, G. B., Chen, H., and Lee, C. F.: Replay of the 1987 Val Pola landslide, Italian Alps, Geomorphology, 60, 127-146, https://doi.org/10.1016/j.geomorph.2003.07.015, 2004.

Crosta, G. B., Frattini, P., and Fusi, N.: Fragmentation in the Val Pola rock avalanche, Italian Alps, J. Geophys. Res., 112, F01006, https://doi.org/10.1029/2005JF000455, 2007.

Cui, P., Chen, X. Q., Zhu, Y. Y., Su, F. H., Wei, F. Q., Han, Y. S., Liu, H. J., and Zhuang, J. Q.: The Wenchuan earthquake (May 12, 2008), Sichuan province, China, and resulting geohazards, Nat. Hazards, 56, 19-36, https://doi.org/10.1007/s11069009-9392-1, 2011.

D’Agostino, N., Avallone, A., Cheloni, D., D’Anastasio, E., Mantenuto, S., and Selvaggi, G.: Active tectonics of the Adriatic region from GPS and earthquake slip vectors, J. Geophys. Res., 113, B12413, https://doi.org/10.1029/2008JB005860, 2008.

Dal Piaz, G.: Studi geotettonici sulle Alpi orientali: regione fra il Brenta e i dintorni del lago di Santa Croce, Mem. Ist. Geol. R. Univ. Padova, 1, 1-195, 1912.

De Zorzi, M.: The Peron Mount rock avalanche: ${ }^{36} \mathrm{Cl}$ exposure age dating, MS thesis, University of Padova, Padova, Italy, 2013.

Di Giusto, M.: Pericolosità indotta dalla caduta massi dal Monte Peron - Valutazione geologica, Technical evaluation for the municipality of Peron, Belluno, Italy, 2012.

Doglioni, C.: The global tectonic pattern, J. Geodyn., 12, 21-38, https://doi.org/10.1016/0264-3707(90)90022-M, 1990.
Dufresne, A.: Granular flow experiments on the interaction with stationary runout path materials and comparison to rock avalanche events, Earth Surf. Proc. Land., 37, 1527-1541, https://doi.org/10.1002/esp.3296, 2012.

Dufresne, A., Prager, C., and Bösmeier, A.: Insights into rock avalanche emplacement processes from detailed morpho-lithological studies of the Tschirgant deposit (Tyrol, Austria), Earth Surf. Proc. Land., 41, 587-602, https://doi.org/10.1002/esp.3847, 2016.

Dunning, S. A., Petley, D. N., Rosser, N. J., and Strom, A. L.: The morphology and sedimentology of valley confined rockavalanche deposits and their effect on potential dam hazard, in: Proceedings of the International Conference on Landslide Risk Management, edited by: Hungr, O., Fell, R., Couture, R., and Eberhardt, E., Taylor and Francis, Balkema, London, UK, 691701, https://doi.org/10.1201/9781439833711, 2005.

Dunning, S. A., Rosser, N. J., Petley, D. N., and Massey, C. R.: Formation and failure of the Tsatichhu landslide dam, Bhutan, Landslides, 3, 107-113, https://doi.org/10.1007/s10346-005-0032-x, 2006.

Dunning, S. A., Mitchell, W. A., Rosser, N. J., and Petley, D. N.: The Hattian Bala rock avalanche and associated landslides triggered by the Kashmir Earthquake of 8 October 2005, Eng. Geol., 93, 130-144, https://doi.org/10.1016/j.enggeo.2007.07.003, 2007.

Eisbacher, G. H. and Clague, J. J.: Destructive mass movements in high mountains: hazard and management, Geological Survey of Canada, Vancouver, British Columbia, Canada, 1984.

Ermini, L. and Casagli, N.: Prediction of the behaviour of landslide dams using a geomorphological dimensionless index, Earth Surf Proc. Land., 28, 31-47, https://doi.org/10.1002/esp.424, 2003.

Evans, S. G., Guthrie, R. H., Roberts, N. J., and Bishop, N. F.: The disastrous 17 February 2006 rockslide-debris avalanche on Leyte Island, Philippines: a catastrophic landslide in tropical mountain terrain, Nat. Hazards Earth Syst. Sci., 7, 89-101, https://doi.org/10.5194/nhess-7-89-2007, 2007.

Filipponi, M., Jeannin, P. Y., and Tacher, L.: Evidence of inception horizons in karst conduit networks, Geomorphology, 106, 86-99, https://doi.org/10.1016/j.geomorph.2008.09.010, 2009.

Frassine, M., Naponiello, G., De Francesco, S., and Asta, A.: RAPTOR 1.5. Aggiornamenti e sperimentazione, in: ArcheoFOSS Free, Libre and Open Source Software e Open Format nei processi di ricerca archeologica, Atti del IX Workshop (Verona, 1920 giugno 2014), edited by: Basso, P., Caravale, A., and Grossi, P., Archeol. Calc. Suppl., 8, 61-71, 2016.

Friedmann, S. J., Kwon, G., and Losert, W.: Granular memory and its effect on the triggering and distribution of rock avalanche events, J. Geophys. Res.-Solid., 108, 2380, https://doi.org/10.1029/2002JB002174, 2003.

Friedmann, S. J., Taberlet, N., and Losert, W.: Rock-avalanche dynamics: insights from granular physics experiments, Int. J. Earth Sci., 95, 911-919, https://doi.org/10.1007/s00531-006-0067-9, 2006.

Galadini, F., Poli, M. E., and Zanferrari, A.: Seismogenic sources potentially responsible for earthquakes with $M \geq 6$ in the eastern Southern Alps (Thiene-Udine sector, NE Italy), Geophys. J. Int., 161, 739-762, https://doi.org/10.1111/j.1365246X.2005.02571.x, 2005. 
Geertsema, M., Clague, J. J., Schwab, J. W., and Evans, S. G.: An overview of recent large catastrophic landslides in northern British Columbia, Canada, Eng. Geol., 83, 120-143, https://doi.org/10.1016/j.enggeo.2005.06.028, 2006.

Genevois, R., Armento, C., and Tecca, P. R.: Failure mechanisms and runout behaviour of three rock avalanches in the north-eastern Italian Alps, in: Landslides from Massive Rock Slope Failure, edited by: Evans, S. G., Mugnozza, G. S., Strom, A., and Hermanns, R. L., NATO Sci. S., 49, 407-427, https://doi.org/10.1007/978-1-4020-4037-5_22, 2006.

Gischig, V., Preisig, G., and Eberhardt, E.: Numerical investigation of seismically induced rock mass fatigue as a mechanism contributing to the progressive failure of deepseated landslides, Rock Mech. Rock Eng., 49, 2457-2478, https://doi.org/10.1007/s00603-015-0821-z, 2016.

Grämiger, L. M., Moore, J., Vockenhuber, C., Aaron, J., Hajdas, I., and Ivy-Ochs, S.: Two early Holocene rock avalanches in the Bernese Alps (Rinderhorn, Switzerland), Geomorphology, 268, 207-221, https://doi.org/10.1016/j.geomorph.2016.06.008, 2016.

Guidoboni, E., Comastri, A., and Boschi, E.: The "exceptional" earthquake of 3 January 1117 in the Verona area (northern Italy): a critical time review and detection of two lost earthquakes (lower Germany and Tuscany), J. Geophys. Res.-Solid, 110, B12309, https://doi.org/10.1029/2005JB003683, 2005.

Guidoboni, E., Ferrari, G., Mariotti, D., Comastri, A., Tarabusi, G., Sgattoni, G., and Valensise, G.: CFTI5Med, Catalogo dei Forti Terremoti in Italia (461 a.C.-1997) e nell'area Mediterranea (760 a.C.-1500), Istituto Nazionale di Geofisica e Vulcanologia (INGV), available at: http://storing.ingv.it/cfti/cfti5 (last access: April 2020), 2018.

Gutierrez, F., Parise, M., DeWaele, J., and Jourde, H.: A review on natural and human-induced geohazards and impacts in karst, Earth-Sci. Rev., 138, 61-88, https://doi.org/10.1016/j.earscirev.2014.08.002, 2014.

Guzzetti, F.: Landslide fatalities and the evaluation of landslide risk in Italy, Eng. Geol., 58, 89-107, https://doi.org/10.1016/S00137952(00)00047-8, 2000.

Guzzetti, F., Peruccacci, S., Rossi, M., and Stark, C. P.: The rainfall intensity-duration control of shallow landslides and debris flows: an update, Landslides, 5, 3-17, https://doi.org/10.1007/s10346007-0112-1, 2008.

Heim, A.: Bergsturz und Menschenleben, Vierteljahrschr. Naturf. Ges. Zürich, 20, Beer and Co., Zurich, Switzerland, 1932.

Hermanns, R. L. and Longva, O.: Rapid rock-slope failures, in: Landslides (types, mechanisms and modeling), edited by: Clague, J. J. and Stead, D., Cambridge University Press, Cambridge, UK, 59-70, https://doi.org/10.1017/CBO9780511740367.007, 2012.

Hermanns, R. L., Niedermann, S., Ivy-Ochs, S., and Kubik, P. W.: Rock avalanching into a landslide-dammed lake causing multiple dam failure in Las Conchas valley (NW Argentina) - evidence from surface exposure dating and stratigraphic analyses, Landslides, 1, 113-122, https://doi.org/10.1007/s10346-004-0013-5, 2004.

Hewitt, K.: Styles of rock avalanche depositional complexes conditioned by very rugged terrain, Karakoram Himalaya, Pakistan, in: Catastrophic landslides: effects, occurrence and mechanisms, edited by: Evans, S. G. and Degraff, J., Geol. Soc. Am. Rev.
Eng. Geol., XV, 345-377, https://doi.org/10.1130/REG15-p345, 2002.

Hewitt, K.: Rock avalanches with complex runout and emplacement, Karakoram Himalaya, Inner Asia, in: Landslides from Massive Rock Slope Failure, edited by: Evans, S. G., ScarasciaMugnozza, G., Strom, A. L., and Hermanns, R. L., NATO Sci. S., 49, 521-550, https://doi.org/10.1007/978-1-4020-4037-5_28, 2006.

Hewitt, K., Clague, J. J., and Orwin, J. F.: Legacies of catastrophic rock slope failures in mountain landscapes, Earth-Sci. Rev., 87, 1-38, https://doi.org/10.1016/j.earscirev.2007.10.002, 2008.

Hoernes, R.: Der Querbruch von Santa Croce und die Bildung der Schuttmassen von Cima Fadalto und der Rovine di Vedana bei Belluno, Zeitschrift der Deutschen Geologischen Gesellschaft, Schweizerbart Science Publishers, Stuttgart, Germany, 347-351, 1892.

Hungr, O.: Landslide hazard assessment - goals and challenges, Inn. Ass. Prof. Eng. Geosci., 8, 12-15, 2004.

Hungr, O.: Rock avalanche occurrence, process and modelling, in: Landslides from Massive Rock Slope Failure, edited by: Evans, S. G., Scarascia-Mugnozza, G., Strom, A. L., and Hermanns, R. L., NATO Sci. S., 49, 243-266, https://doi.org/10.1007/978-14020-4037-5_14, 2006.

Hungr, O., Evans, S. G., and Hutchinson, I. N.: A Review of the Classification of Landslides of the Flow Type, Environ. Eng. Geosci., 7, 221-238, https://doi.org/10.2113/gseegeosci.7.3.221, 2001.

Ivy-Ochs, S., Synal, H. A., Roth, C., and Schaller, M.: Initial results from isotope dilution for $\mathrm{Cl}$ and ${ }^{36} \mathrm{Cl}$ measurements at the PSI/ETH Zurich AMS facility, Nucl. Instrum. Meth. B, 223-224, 623-627, https://doi.org/10.1016/j.nimb.2004.04.115, 2004.

Ivy-Ochs, S., Martin, S., Campedel, P., Hippe, K., Alfimov, V., Vockenhuber, C., Andreotti, E., Carugati, G., Pasqual, D., Rigo, M., and Viganò, A.: Geomorphology and age of the Marocche di Dro rock avalanches (Trentino, Italy), Quaternary Sci. Rev., 169, 188-205, https://doi.org/10.1016/j.quascirev.2017.05.014, 2017.

Keefer, D. K.: The susceptibility of rock slopes to earthquakeinduced failure, Bull. Assoc. Eng. Geol., 30, 353-361, 1993.

Köpfli, P., Grämiger, L. M., Moore, J. R., Vockenhuber, C., and Ivy-Ochs, S.: The Oeschinensee rock avalanche, Bernese Alps, Switzerland: a co-seismic failure 2300 years ago?, Swiss J. Geosci., 111, 205-219, https://doi.org/10.1007/s00015-0170293-0, 2018.

Loew, S., Gischig, V., Willenberg, H., Alpiger, A., and Moore, J.: Randa: kinematics and driving mechanisms of a large complex rockslide, in: Landslides: Types, Mechanisms and Modeling, edited by: Clague, J. and Stead, D., Cambridge University Press, Cambridge, UK, 297-309, https://doi.org/10.1017/CBO9780511740367.025, 2012.

Loew, S., Gschwind, S., Gischig, V., Keller-Signer, A., and Valenti, G.: Monitoring and early warning of the 2012 Preonzo catastrophic rockslope failure, Landslides, 14, 141-154, https://doi.org/10.1007/s10346-016-0701-y, 2017.

Macklin, M. G., Benito, G., Gregory, K. J., Johnstone, E., Lewin, J., Michczyńska, D. J., Soja, R., Starkel, L., and Thorndycraft, V. R.: Past hydrological events reflected in the Holocene fluvial record of Europe, Catena, 66, 145-154, https://doi.org/10.1016/j.catena.2005.07.015, 2006. 
Magoga, L. S. and Marin, F. (Eds.): La certosa di Vedana. Storia, cultura e arte in un ambiente delle Prealpi Bellunesi, Leo S. Olschki, Florence, Italy, 1998.

Mangeney, A., Roche, O., Hungr, O., Mangold, N., Faccanoni, G., and Lucas, A.: Erosion and mobility in granular collapse over sloping beds, J. Geophys. Res.-Earth, 115, F03040, https://doi.org/10.1029/2009JF001462, 2010.

Marrero, S. M., Phillips, F. M., Caffee, M. W., and Gosse, J. C.: CRONUS-Earth cosmogenic ${ }^{36} \mathrm{Cl}$ calibration, Quat. Geochronol., 31, 199-219, https://doi.org/10.1016/j.quageo.2015.10.002, 2016.

Martin, S., Campedel, P., Ivy-Ochs, S., Viganò, A., Alfimov, V., Vockenhuber, C., Andreotti, E., Carugati, G., Pasqual, D., and Rigo, M.: Lavini di Marco (Trentino, Italy): ${ }^{36} \mathrm{Cl}$ exposure dating of a polyphase rock avalanche, Quat. Geochronol., 19, 106-116, https://doi.org/10.1016/j.quageo.2013.08.003, 2014.

Márton, E., Drobne, K., Ćosović, V., and Moro, A.: Palaeomagnetic evidence for Tertiary counterclockwise rotation of Adria, Tectonophysics, 377, 143-156, https://doi.org/10.1016/j.tecto.2003.08.022, 2003.

Masetti, D. and Bianchin, G.: Geologia del Gruppo dello Schiara (Dolomiti Bellunesi): Suo inquadramento nell'evoluzione giurassica del margine orientale della piattaforma di Trento, Mem. Sci. Geol., 39, 187-212, 1987.

Mazzuoli, L.: Sull'origine delle rovine di Vedana, Club Alpino Italiano, sez. di Agordo, Adunanza straordinaria dei soci il 228-1875 in Vedana, Tipografia Guernieri, Belluno, Italy, 11-17, 1875.

Merchel, S., Braucher, R., Alfimov, V., Bichler, M., Bourlès, D. L., and Reitner, J. M.: The potential of historic rock avalanches and man-made structures as chlorine-36 production rate calibration sites, Quat. Geochronol., 18, 54-62, https://doi.org/10.1016/j.quageo.2013.07.004, 2013.

Miari, F.: Compendio storico della regia citta di Belluno e sua antica provincia, Giuseppe Picotti, Venezia, Italy, 1830.

Mitchell, W. A., McSaveney, M. J., Zondervan, A., Kim, K., Dunning, S. A., and Taylor, P. J.: The Keylong Serai rock avalanche, NW Indian Himalaya: geomorphology and palaeoseismic implications, Landslides, 4, 245-254, https://doi.org/10.1007/s10346007-0085-0, 2007.

Mitchell, W. A., McDougall, S., Nolde, N., Brideau, M. A., Whittall, J., and Aaron, J. B.: Rock avalanche runout prediction using stochastic analysis of a regional dataset, Landslides, 17, 777792, https://doi.org/10.1007/s10346-019-01331-3, 2020.

Montandon, F.: Chronologie des grands éboulements alpins du début de l'ère chrétienne à nos jours, Matér. étude calam., 32, 271-337, 1933.

More, K. S. and Wolkersdorfer, C.: An analogue Toma Hill formation model for the Tyrolian Fernpass rockslide, Landslides, 16, 1855-1870, https://doi.org/10.1007/s10346-019-01211-w, 2019.

Nicoletti, P. G. and Sorriso-Valvo, M.: Geomorphic controls of the shape and mobility of rock avalanches, Geol. Soc. Am. Bull., 103, 1365-1373, https://doi.org/10.1130/00167606(1991)103<1365:GCOTSA>2.3.CO;2, 1991.

Ostermann, M., Ivy-Ochs, S., Sanders, D., and Prager, C.: Multimethod $\left({ }^{14} \mathrm{C},{ }^{36} \mathrm{Cl},{ }^{234} \mathrm{U} /{ }^{230} \mathrm{Th}\right)$ age bracketing of the Tschirgant rock avalanche (Eastern Alps): implications for absolute dating of catastrophic mass-wasting, Earth Surf. Proc. Land., 42, 1110-1118, https://doi.org/10.1002/esp.4077, 2017.
Pánek, T., Hradecký, J., Šilhán, K., Smolková, V., and Altová, V.: Time constraints for the evolution of a large slope collapse in karstified mountainous terrain of the southwestern Crimean Mountains, Ukraine, Geomorphology, 108, 171-181, https://doi.org/10.1016/j.geomorph.2009.01.003, 2009.

Parker, R., Petley, D., Densmore, A., Rosser, N., Damby, D., and Brain, M.: Progressive failure cycles and distributions of earthquake-triggered landslides, in: EarthquakeInduced Landslides, edited by: Ugai, K., Yagi, H., and Wakai, A., Springer, Berlin, Heidelberg, Germany, 755-762, https://doi.org/10.1007/978-3-642-32238-9_82, 2013.

Patzelt, G.: The rock avalanches of Tschirgant and Haiming (Upper Inn Valley, Tyrol, Austria), comment on the map supply, Jb. Geol. B-A, 152, 13-24, 2012.

Pellegrini, G. B. (Ed.): Note illustrative della Carta Geomorfologica d'Italia - Foglio Belluno, Regione Veneto - Servizio Geologico d'Italia, Rome, Italy, 2000.

Pellegrini, G. B. and Caneve, L.: Carta geomorfologica delle Masiere di Vedana nel Vallone Bellunese (Belluno) - scale 1: 25, 000, S.EL.CA., Florence, Italy, 2005.

Pellegrini, G. B. and Surian, N.: Geomorphological study of the Fadalto landslide, Venetian Prealps, Italy, Geomorphology, 15, 337-350, https://doi.org/10.1016/0169-555X(95)00079K, 1996.

Pellegrini, G. B., Surian, N., and Albanese, D.: Landslide activity in response to alpine deglaciation: the case of the Belluno Prealps (Italy), Geogr. Fis. Din. Quat., 29, 185-196, 2006.

Piloni, G.: Historia della Citta di Belluno, Arnaldo Forni Editore, Venice, Italy, 1607.

Prager, C., Ivy-Ochs, S., Ostermann, M., Synal, H. A., and Patzelt, G.: Geology and radiometric ${ }^{14} \mathrm{C}-,{ }^{36} \mathrm{Cl}$ - and Th-/U-dating of the Fernpass rockslide (Tyrol, Austria), Geomorphology, 103, 93103, https://doi.org/10.1016/j.geomorph.2007.10.018, 2009.

Preisig, G., Gischig, V., Eberhardt, E., and Hungr, O.: Hydromechanical versus seismic fatigue in progressive failure of deepseated landslides, in: 13th ISRM International Congress of Rock Mechanics. International Society for Rock Mechanics and Rock Engineering, 10-13 May 2015, Montreal, Canada, https://doi.org/10.13140/RG.2.1.2565.0081, 2015.

Rossato, S., Fontana, A., and Mozzi, P.: Meta-analysis of a Holocene ${ }^{14} \mathrm{C}$ database for the detection of paleohydrological crisis in the Venetian-Friulian Plain (NE Italy), Catena, 130, 34 45, https://doi.org/10.1016/j.catena.2014.10.033, 2015.

Rossato, S., Martin, S., Ivy-Ochs, S., Viganò, A., Vockenhuber, C., Rigo, M., Surian, N., and Mozzi, P.: PostLGM catastrophic landslides in the Dolomites: when, where and why, Alp. Mediterr. Quat., 31, 239-242, https://doi.org/10.26382/AIQUA.2018.AIQUAconference, 2018.

Rovida, A. N., Locati, M., Camassi, R. D., Lolli, B., and Gasperini, P. (Eds.): CPTI15, the 2015 version of the Parametric Catalogue of Italian Earthquakes, Istituto Nazionale di Geofisica e Vulcanologia, Rome, Italy, https://doi.org/10.6092/INGV.ITCPTI15, 2016.

Samia, J., Temme, A., Bregt, A., Wallinga, J., Guzzetti, F., Ardizzone, F., and Rossi, M.: Do landslides follow landslides? Insights in path dependency from a multi-temporal landslide inventory, Landslides, 14, 547-558, https://doi.org/10.1007/s10346016-0739-x, 2017. 
Sandron, D., Renner, G., Rebez, A., and Slejko, D.: Early instrumental seismicity recorded in the eastern Alps, B. Geofis. Teor. Appl., 55, 755-788, https://doi.org/10.4430/bgta0118, 2014.

Sauro, F., Zampieri, D., and Filipponi, M.: Development of a deep karst system within a transpressional structure of the Dolomites in north-east Italy, Geomorphology, 184, 51-63, https://doi.org/10.1016/j.geomorph.2012.11.014, 2013.

Schuster, R. L. and Wieczorek, G. F.: Landslide triggers and types, in: Landslides: proceedings of the first European conference on landslides, edited by: Rybár, J., Stemberk, J., and Wagner, P., Taylor and Francis, Prague, Czech Republic, 59-78, 2002.

Sewell, R. J., Barrows, T. T., Campbell, S. D. G., and Fifield, L. K.: Exposure dating $\left({ }^{10} \mathrm{Be},{ }^{26} \mathrm{Al}\right)$ of natural terrain landslides in Hong Kong, China, Geol. S. Am. S., 415, 131-146, https://doi.org/10.1130/2006.2415(08), 2006.

Sosio, R., Crosta, G. B., and Hungr, O.: Complete dynamic modeling calibration for the Thurwieser rock avalanche (Italian Central Alps), Eng. Geol., 100, 11-26, https://doi.org/10.1016/j.enggeo.2008.02.012, 2008.

Spreafico, M. C., Wolter, A., Picotti, V., Borgatti, L., Mangeney, A., and Ghirotti, M.: Forensic investigations of the Cima Salti Landslide, northern Italy, using runout simulations, Geomorphology, 318, 172-186, https://doi.org/10.1016/j.geomorph.2018.04.013, 2018.

Squinabol, S.: Venti giorni sui Monti Bellunesi, Tip. Raffaello Giusti, Livorno, Italy, 1902.

Stead, D. and Eberhardt, E.: Understanding the mechanics of large landslides, Ital. J. Eng. Geol. Environ. Book Ser., 6, 85-112, https://doi.org/10.4408/IJEGE.2013-06.B-07, 2013.

Stead, D. and Wolter, A.: A critical review of rock slope failure mechanisms: the importance of structural geology, J. Struct. Geol., 74, 1-23, https://doi.org/10.1016/j.jsg.2015.02.002, 2015.

Stone, J. O.: Air pressure and cosmogenic isotope production, J. Geophys. Res.-Solid, 105, 23753-23759, https://doi.org/10.1029/2000JB900181, 2000.

Strom, A.: Morphology and internal structure of rockslides and rock avalanches: grounds and constraints for their modelling, in: Landslides from Massive Rock Slope Failure, edited by: Evans, S. G., Mugnozza, G. S., Strom, A., and Hermanns, R. L., NATO Sci. S., 49, 305-326, https://doi.org/10.1007/978-1-4020-40375_17, 2006.

Styllas, M. N., Schimmelpfennig, I., Benedetti, L., Ghilardi, M., and ASTER Team: Late-glacial and Holocene history of the northeast Mediterranean mountains-New insights from in situ-produced ${ }^{36} \mathrm{Cl}$-based cosmic ray exposure dating of paleo-glacier deposits on Mount Olympus, Greece, Quaternary Sci. Rev., 193, 244-265, https://doi.org/10.1016/j.quascirev.2018.06.020, 2018.

Takahashi, T.: Process of occurrence, flow and deposition of viscous debris flow, in: River, Coastal and Estuarine Morphodynamics, edited by: Seminara, G. and Blondeaux, P., Springer, Berlin, Germany, 93-118, https://doi.org/10.1007/978-3-66204571-8_5, 2001.
Taramelli, T.: Note alla Carta Geologica della Provincia di Belluno, Ed. Fusi, Pavia, Italy, 1883.

Trigila, A., Iadanza, C., and Guerrieri, L.: The IFFI project (Italian landslide inventory): Methodology and results, in: Guidelines for Mapping Areas at Risk of Landslides in Europe, edited by: Hervás, J., ISPRA, Rome, Italy, 15-18, https://doi.org/10.2788/63147, 2007.

Trigila, A., Iadanza, C., Bussettini, M., and Lastoria, B.: Dissesto idrogeologico in Italia: pericolosità e indicatori di rischio, Edizione 2018, Rapporti 287/2018, ISPRA, Rome, Italy, 2018.

Tsai, T. L. and Wang, J. K.: Examination of influences of rainfall patterns on shallow landslides due to dissipation of matric suction, Environ. Earth Sci., 63, 65-75, https://doi.org/10.1007/s12665-010-0669-1, 2011.

Turnau, V.: Beiträge zur Geologie der Berner-Alpen, 1. Der prähistorische Bergsturz von Kandersteg, 2, Buchdruckerei KJ Wyss, Bern, Switzerland, 1906.

Venzo, S.: Osservazioni geotettoniche e geomorfologiche sul rilevamento del Foglio Belluno, B. Soc. Geol. Ital., 58, 433-451, 1939.

Viganò, A., Scafidi, D., Martin, S., and Spallarossa, D.: Structure and properties of the Adriatic crust in the central-eastern Southern Alps (Italy) from local earthquake tomography, Terra Nova, 25, 504-512, https://doi.org/10.1111/ter.12067, 2013.

Viganòò, A., Scafidi, D., Ranalli, G., Martin, S., Della Vedova, B., and Spallarossa, D.: Earthquake relocations, crustal rheology, and active deformation in the centraleastern Alps (N Italy), Tectonophysics, 661, 81-98, https://doi.org/10.1016/j.tecto.2015.08.017, 2015.

Vockenhuber, C., Miltenberger, K. U., and Synal, H. A.: ${ }^{36} \mathrm{Cl}$ measurements with a gas-filled magnet at 6 MV, Nucl. Instrum. Meth. B, 455, 190-194, https://doi.org/10.1016/j.nimb.2018.12.046, 2019.

von Poschinger, A. and Ruegg, T.: Die Churer Tomahügel, ein besonderes Zeugnis der Landschaftsgenese, Jber. Natf. Ges. Graubünden, 117, 93-100, 2012.

Welkner, D., Eberhardt, E., and Hermanns, R. L.: Hazard investigation of the Portillo Rock Avalanche site, central Andes, Chile, using an integrated field mapping and numerical modelling approach, Eng. Geol., 114, 278-297, https://doi.org/10.1016/j.enggeo.2010.05.007, 2010.

Wieczorek, G. F.: Landslide triggering mechanisms, in: Landslides: Investigation and Mitigation, edited by: Turner, A. K. and Schuster, R. L., Transportation Research Board, Special Report, National Research Council, Washington, D.C., USA, 76-90, 1996.

Wirth, S. B., Glur, L., Gilli, A., and Anselmetti, F. S.: Holocene flood frequency across the Central Alps - solar forcing and evidence for variations in North Atlantic atmospheric circulation, Quaternary Sci. Rev., 80, 112-128, https://doi.org/10.1016/j.quascirev.2013.09.002, 2013. 